\title{
Yedoma Ice Complex of the Buor Khaya Peninsula (southern Laptev Sea)
}

\author{
Lutz Schirrmeister $^{1}$, Georg Schwamborn ${ }^{1}$, Pier Paul Overduin ${ }^{1}$, Jens Strauss ${ }^{1}$, Margret C. Fuchs ${ }^{2}$, \\ Mikhail Grigoriev $^{3}$, Irina Yakshina ${ }^{4}$, Janet Rethemeyer ${ }^{5}$, Elisabeth Dietze $^{6}$, and Sebastian Wetterich ${ }^{1}$ \\ ${ }^{1}$ Department of Periglacial Research, Alfred Wegener Institute Helmholtz Center for Polar and Marine Research, Potsdam \\ 14473, Germany \\ ${ }^{2}$ Helmholtz Institute Freiberg for Resource Technology, Helmholtz-Zentrum Dresden-Rossendorf, Freiberg 09599, Germany \\ ${ }^{3}$ Mel'nikov Permafrost Institute, Siberian Branch of the Russian Academy of Science, Yakutsk, 677010, Russia \\ ${ }^{4}$ Lena Delta Reserve, Tiksi, 678400, Russia \\ ${ }^{5}$ Institute of Geology and Mineralogy, University of Cologne, Cologne 50674, Germany \\ ${ }^{6}$ GFZ German Research Centre for Geosciences, Section 5.2 Climate Dynamics and Landscape Evolution, Potsdam 14473, \\ Germany
}

Correspondence to: Lutz Schirrmeister (lutz.schirrmeister@awi.de)

Received: 7 July 2016 - Discussion started: 2 August 2016

Revised: 24 February 2017 - Accepted: 28 February 2017 - Published: 15 March 2017

\begin{abstract}
The composition of perennially frozen deposits holds information on the palaeo-environment during and following deposition. In this study, we investigate late Pleistocene permafrost at the western coast of the Buor Khaya Peninsula in the south-central Laptev Sea (Siberia), namely the prominent eastern Siberian Yedoma Ice Complex (IC). Two Yedoma IC exposures and one drill core were studied for cryolithological (i.e. ice and sediment features), geochemical, and geochronological parameters. Borehole temperatures were measured for 3 years to capture the current thermal state of permafrost. The studied sequences were composed of ice-oversaturated silts and fine-grained sands with considerable amounts of organic matter ( 0.2 to $24 \mathrm{wt} \%$ ). Syngenetic ice wedges intersect the frozen deposits. The deposition of the Yedoma IC, as revealed by radiocarbon dates of sedimentary organic matter, took place between 54.1 and $30.1 \mathrm{kyr}$ BP. Continued Yedoma IC deposition until about $14.7 \mathrm{kyr} \mathrm{BP}$ is shown by dates from organic matter preserved in ice-wedge ice. For the lowermost and oldest Yedoma IC part, infrared-stimulated luminescence dates on feldspar show deposition ages between $51.1 \pm 4.9$ and $44.2 \pm 3.6 \mathrm{kyr} B$ P. End-member modelling was applied to grain-size-distribution data to determined sedimentation processes during Yedoma IC formation. Three to five robust end-members were detected within Yedoma IC deposits,
\end{abstract}

which we interpret as different modes of primary and reworked unconfined alluvial slope and fan deposition as well as of localized eolian and fluvial sediment, which is overprinted by in situ frost weathering. The cryolithological inventory of the Yedoma IC preserved on the Buor Khaya Peninsula is closely related to the results of other IC studies, for example, to the west on the Bykovsky Peninsula, where formation time (mainly during the late Pleistocene marine isotope stages (MIS) 3 interstadial) and formation conditions were similar. Local freezing conditions on Buor Khaya, however, differed and created solute-enriched (salty) and isotopically light pore water pointing to a small talik layer and thawbulb freezing after deposition. Due to intense coastal erosion, the biogeochemical signature of the studied Yedoma IC represents the terrestrial end-member, and is closely related to organic matter currently being deposited in the marine realm of the Laptev Sea shelf.

\section{Introduction}

In recent years, considerable research on Quaternary permafrost has focused on a prominent feature of late Pleistocene deposit that is named in stratigraphic terms as Yedoma Ice Complex (IC), according to Tumskoy (2012) and 
Schirrmeister et al. (2013). The Yedoma IC formed in nonglaciated Beringia between approx. 60 and $12 \mathrm{kyr} \mathrm{BP}$ (marine isotope stages (MIS) 4 to 2), including stadial and interstadial stages of the late Pleistocene, although the ages of preserved deposits vary from site to site (Schirrmeister et al., 2011b). Yedoma IC formed in polygonal tundra environments with syngenetic ice-wedge growth. Ice wedges originate from repeated frost cracking of frozen ground in winter and subsequent crack filling by snowmelt water in spring and its re-freezing in the ground. The presence of huge syngenetic ice wedges (up to decametres tall and metres wide) is recognized as characteristic for Yedoma IC, while the depositional processes and sediment sources are still under debate (e.g. Murton et al., 2015). Different depositional regimes are assumed to produce polymodal grain-size distributions, which are commonly found in Yedoma IC (Schirrmeister et al., 2011b). But similar landscape and relief characteristics (poorly drained flat accumulation plains with polygonal patterned ground), cold-arid climate conditions, periglacial processes, such as cryoturbation, frost cracking, syngenetic freezing, and short-path transport of mineral material control Yedoma IC formation (Sher, 1997).

The modern periglacial surface exposes Yedoma IC remnants in Alaskan and eastern Siberian lowlands next to widely distributed thermokarst basins (alases). They were formed after late-glacial-Holocene warming had eroded up to $70 \%$ of the original IC distribution by thawing in an area of more than $1000000 \mathrm{~km}^{2}$ (Strauss et al., 2013). On the Buor Khaya Peninsula, $85 \%$ of the land surface is affected by late-glacial/Holocene to modern thermokarst (Morgenstern et al., 2017).

Numerous case studies have applied multi-proxy approaches at several sites in north-eastern Siberia including the stratotype outcrop for Yedoma IC at Duvanny Yar, which is exposed at the Kolyma River bank (e.g. Gubin and Zanina, 2013; Murton et al., 2015; Strauss et al., 2012). Poorly sorted silts and fine-grained sands compose Yedoma IC deposits, which are ice rich with segregation ice contents between 40 and $60 \mathrm{wt} \%$ (Schirrmeister et al., 2011b), and are intersected by ice wedges, which constitute between 31 and $63 \mathrm{vol} \%$ of the Yedoma IC (Ulrich et al., 2014). The total ice content of Yedoma IC reaches up to $80 \mathrm{vol} \%$. Lens-like (lenticular) or net-like (reticulated) intrasedimentary ice structures (cryostructures) alternating with horizontal ice bands indicate ice segregation near the permafrost table and syngenetic freezing shortly after deposition. Pronounced ice-wedge shoulders indicate the stepwise transformation of seasonally unfrozen into perennially frozen deposits due to varying thaw (active) layer depths during formation of syngenetic permafrost.

Yedoma IC is rich in well-preserved floral and faunal fossils, and represents late Quaternary Beringian tundrasteppe environments. Palaeontological proxies, such as testate amoebae (Bobrov et al., 2004; Müller et al., 2009), pollen (Andreev et al., 2011), plant macrofossils (Kienast et al., 2005), ostracods (Wetterich et al., 2005), and insect fossils and bones of the mammoth fauna (Sher et al., 2005; Wetterich et al., 2008), give insights into past ecosystem and climate conditions, mainly for the summer season. Winter climate during IC formation is commonly deduced from ice-wedge stable water-isotope signatures (e.g. Meyer et al., 2002a, b; Vasil'chuk et al., 2001; Vasil'chuk, 2013) that differentiate at least interstadial and stadial stages of the last glacial period (Wetterich et al., 2011b, 2014). The combination of summer and winter proxies sheds light on seasonal trends of past climate and their roles in environmental dynamics.

Eroding Yedoma IC deposits are considered as a major source of terrigenic organic carbon transfer into the Arctic Ocean (Vonk et al., 2012; Winterfeld et al., 2015; Bröder et al., 2016) and represent the terrestrial end-member of organic matter (OM) on the East Siberian Arctic Shelf (Bischoff et al., 2016). Buried cryosols of Yedoma IC enriched in OM are striking and contribute to a mean total organic carbon (TOC) content of $3 \mathrm{wt} \%$ in Yedoma IC (Strauss et al., 2013), which mainly varies between 1 and $5 \mathrm{wt} \%$ (Schirrmeister et al., 2011a). Using TC values, Shmelev et al. (2017) estimated 0.6 to $2.1 \%$ TC of carbon storage in permafrost of northeastern Yakutia. The fossil OM of Yedoma IC is the subject of ongoing research to estimate the permafrost-locked carbon pool (Hugelius et al., 2014) and its potential feedback to recent climate warming (Schneider von Deimling et al., 2015). The baseline TOC estimates are of further use to study OM quality (Strauss et al., 2015; Stapel et al., 2016) and potential availability for microbial turnover of thawing carbon pools to greenhouse gas emissions in a warming Arctic (Knoblauch et al., 2013). Yedoma IC is considered to be an important pool of OM and potential source of carbon, nitrogen, and nutrient release under current warming (Zimov et al., 2006). Therefore, analysis of OM preserved in Yedoma IC can improve quantification and prediction of permafrost feedbacks to climate warming.

The cryolithology of several Yedoma IC sites in the Laptev Sea region is summarized in Schirrmeister et al. (2011b) and Tumskoy (2012). But studies of Yedoma IC in north-eastern Siberia started already several decades earlier (e.g. Tomirdiaro, 1980; Kaplina, 1981; Gubin and Zanina, 2013, 2014, and quotations therein); Yedoma IC with very similar characteristics to north-eastern Siberian sites is reported from the Alaskan Itkillik River in the Arctic foothills (Kanevskiy et al., 2011). Studies of eastern Beringian Yedoma IC were undertaken in permafrost tunnels near Fairbanks (Hamilton et al., 1988; Shur et al., 2004; Bray et al., 2006; Kanevskiy et al., 2008; Schirrmeister et al., 2016). IC of MIS 4 age is well-documented in central Yukon through the presence of the Sheep Creek-K tephra (approx. 80 kyr old; Froese et al., 2009). Further, the presence of IC deposits is known from the Klondike area (Sanborn et al., 2006).

This study summarizes cryolithological (i.e. ice and sediment features), geochemical, and geochronological data of 


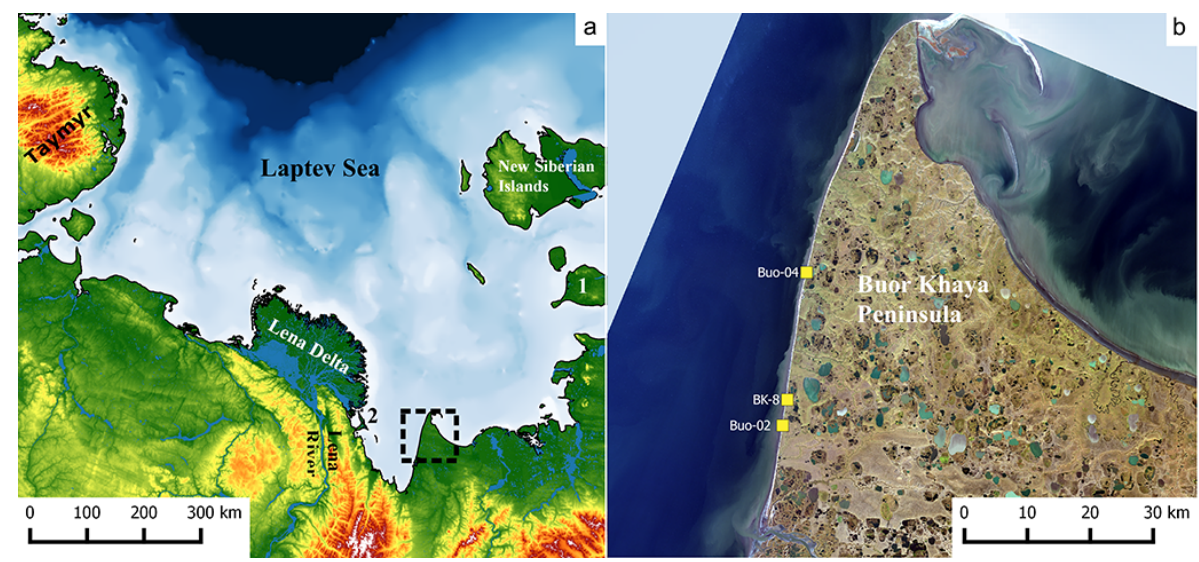

Figure 1. Study area in the central Laptev Sea region (a; based on IBCAO 3.0 Jakobsson et al., 2012) including Buor Khaya Peninsula marked by the black frame and Yedoma IC reference sites on Bol'shoy Lyakhovsky Island (1) and Bykovsky Peninsula (2); position of the study sites Buo-02, Buo-04, and BK-8 at the western coast of the Buor Khaya Peninsula (b; LANDSAT_8 image from 2015).

three Yedoma IC sequences from the Buor Khaya Peninsula in the southern Laptev Sea (Fig. 1). We aim to fill a spatial gap in Yedoma IC research in western Beringia between the intensively studied western and central Laptev Sea regions (including the Lena Delta) to the west (e.g. Schirrmeister et al., 2002, 2008; Wetterich et al., 2008) and the Dmitry Laptev Strait and the New Siberian Archipelago to the east (Andreev et al., 2009).

By capturing the internal variation of Yedoma IC characteristics, the study deduces stratigraphy and correlates the Buor Khaya Yedoma IC records on a regional scale for Beringia. Since cryolithological properties of Yedoma IC vary from site to site and only about 20 Arctic and subarctic sites have been studied in detail so far, any new record provides important data for Beringian palaeo-environmental research. Yedoma IC formation processes have been under discussion for decades and each new sedimentary record gives insights into source material, transport, and deposition processes of this unique stratum, which represents a valuable archive and is a main focus in Arctic permafrost and palaeoenvironmental research.

\section{Study site}

The Buor Khaya Peninsula is part of the Yana-Indigirka coastal lowlands and is located at the south-central Laptev Sea coast (Fig. 1). The vegetation of the Buor Khaya Peninsula is mostly erect dwarf-shrub tundra, with, in places, tussock-sedge and moss tundra (CAVM, 2003). The northernmost part of the peninsula is covered by sedge, moss, and dwarf-shrub wetlands. In total, 77 vascular plant species were recorded during fieldwork in 2010 (Yakshina, 2011).

The subarctic climate is continental, with low precipitation, long harsh winters, and short cold summers. The mean annual air temperature at the closest meteorological station
(WMO station 218240 , Tiksi, 1981 to 2010 ) is $-12.8^{\circ} \mathrm{C}$ (mean temperature of the warmest month, $T_{\text {July }}: 8.7^{\circ} \mathrm{C}$; mean temperature of the coldest month, $T_{\text {January }}:-32.5^{\circ} \mathrm{C}$ ) and mean annual precipitation amounts $321.5 \mathrm{~mm}$.

The region is underlain by continuous permafrost with ground temperatures of less than $-11{ }^{\circ} \mathrm{C}$ (Drozdov et al., 2005), which extends down to 450-650 m (Romanovskii et al., 2004). The Yedoma IC of Buor Khaya Peninsula represents the southernmost extent of near-coastal Yedoma IC in a neotectonically active location south of the Gakkel Ridge landfall.

The Yana-Indigirka coastal lowlands are part of the late Pleistocene accumulation plains of western Beringia. Late-glacial-Holocene warming triggered thermokarst and thermo-erosion, which both have significantly reworked the upper permafrost and shaped the modern surface morphology. Yedoma IC remnants cover $15 \%$ of the area, which consists mainly of coalesced thermokarst basins (alases) and are often occupied by shallow lakes. Yedoma hills reach up to $37 \mathrm{~m}$ above sea level (a.s.1.), and thermokarst basins reach 9 to $14 \mathrm{~m}$ a.s.l. (Günther et al., 2013b).

\section{Materials and methods}

\subsection{Fieldwork}

The fieldwork on two Yedoma exposures on the western coast of the Buor Khaya Peninsula (Buo-02, $71.384^{\circ} \mathrm{N}$, $132.084^{\circ} \mathrm{E}$; Buo-04, $\left.71.600^{\circ} \mathrm{N}, 132.227^{\circ} \mathrm{E}\right)$ was carried out between 3 and 19 August 2010 (Wetterich et al., 2011a). Sediment profiles, partly exposed on thermokarst mounds in thaw slumps, were dug with spades and subsequently cleaned with hoes. The sediments and cryolithological structures were surveyed, described (according to French and Shur, 2010 and Katasonov, 1975), photographed, and sketched. 
The correlation of the sampling position in neighbouring subprofiles was done by height estimation using measuring tape. The upper edges of the profiles were measured by tacheometre measurements (Zeiss ELTA C30) to obtain heights above sea level (a.s.1.) and to relate sub-profiles. Frozen deposits were sampled using hammers and small axes and packed in plastic bags. Supernatant melt water from segregated ice was separated for isotopic analyses. For selected samples without supernatant water, the pore water was sampled using a syringe with vacuum and a micro-filtration membrane $(0.2 \mu \mathrm{m}$ pore size, Rhizon Core Solution Sampler, Eijkelkamp). In addition, ice wedges were sampled using ice screws. The absolute ice content was determined in the field as the ratio of ice weight and the weight of frozen sediment. Frozen samples were taken in aluminium boxes, weighed, dried, and weighed again. The volume of the frozen sample was determined through the volume of water displacement. We used a vacuum pump and blind measurements of the sample bags. Assuming a water density of 1 , the volume of displaced water corresponds to the volume of the sample, which was used for bulk density calculations (Strauss et al., 2013).

Drilling at site BK-8 took place at a distance of approx. $100 \mathrm{~m}$ from the cliff edge on top of a $34.2 \mathrm{~m}$ (a.s.1.) high Yedoma hill $\left(71.4203^{\circ} \mathrm{N}, 132.111^{\circ} \mathrm{E}\right)$ using a Russian drill rig between 24 and 27 April 2012 (Günther et al., 2013a). Core diameters were 127, 108, 89, and $73 \mathrm{~mm}$. Drilling proceeded in a dry rotary mode without fluids and casing. Core recovery began at the ground surface and continued down to a borehole depth of $18.9 \mathrm{~m}$ below surface (b.s.). An ice wedge was encountered and collected between 3.2 and $8.5 \mathrm{mb}$.s. The core was described by colour, OM inclusions, and visible sediment and ice structures. Frozen samples were packed and stored frozen in styrofoam boxes.

Ground temperature was measured in the borehole using a $40 \mathrm{~m}$ GeoPrecision thermistor string with 15 PT1000 sensors, installed shortly after drilling. The sensors were calibrated in a purified water (electrical conductivity (EC) $<1 \mu \mathrm{S} \mathrm{cm}^{-1}$ ) ice bath prior to installation. Sensor output measured in the ice bath was applied as an offset to measured temperatures (1-point calibration). The accuracy of the PT1000 thermistors is better than $\pm 0.1^{\circ} \mathrm{C}$. The temperature record for almost 3 years (11 May 2012-27 April 2015) was read out in late April 2015.

\subsection{Laboratory work}

Sediment samples were freeze-dried, homogenized, and split into sub-samples for further analyses. The volume and weight of frozen and freeze-dried sub-samples were determined for analysis of bulk and dry density and total volumetric moisture content (ice and water). Grain-size analyses were carried out using an LS 200 laser particle analyser (Beckman Coulter, Inc.) after removing OM with hydrogen peroxide $(3 \%)$. The used grain-size classification is according to Reineck and Sing (1980) and Wenthworth (1922). To- tal carbon (TC) and total nitrogen (TN) contents were measured with a VARIO-EL-III Element Analyzer, while TOC content was measured with the VARIO MAX C. Total sulfur (TS) was measured with a carbon-sulfur determinator (Eltra CS 200). Using the TOC and TN values, the TOC / TN ratio was calculated to deduce the degree of OM decomposition. For TOC and stable organic carbon isotope $\left(\delta^{13} \mathrm{C}\right)$ analyses, samples were decalcified for $3 \mathrm{~h}$ at $95^{\circ} \mathrm{C}$ by adding a surplus of $1.3 \mathrm{~N} \mathrm{HCl}$. Total inorganic carbon (TIC) content was calculated by subtracting TOC from TC. The $\delta^{13} \mathrm{C}$ of TOC was measured with a Finnigan DELTA $S$ mass spectrometer and is expressed in delta per mil notation $(\delta \%)$ relative to the Vienna Pee Dee Belemnite standard with an uncertainty of $0.15 \%$. The variations in $\delta^{13} \mathrm{C}$ are indicative of changes in the local vegetation and the decomposition degree of OM (Hoefs, 1997). Mass-specific magnetic susceptibility (MS) indicating the content of magnetic and magnetisable minerals was measured using Bartington MS2 instruments equipped with the MS2B sensor type. The data are expressed in SI units (Le Système International d'Unités, $10^{-8} \mathrm{~m}^{3} \mathrm{~kg}^{-1}$ ).

An end-member modelling analysis (EMMA) was used to determined characteristic grain-size subpopulations that compose the polymodal grain-size distributions at each site. A robust EMMA was run using the EMMAgeo $\mathrm{R}$ package version 0.9.4. EMMAgeo is based on an algorithm developed by Dietze et al. (2012) that relies on principles of factor analyses and includes different transformation steps to determine a few interpretable grain-size subpopulations (loadings, i.e. contribution of grain-size classes to each end-member). Robust end-members (rEMs) are defined as grain-size subpopulations that appear independent of model parametrization (related to a priori unknown numbers of end-members and weight transformation limits; Dietze et al., 2014). Mean rEM loadings and a weight transformation limit of zero were used to calculate mean scores (i.e. relative contribution of an endmember to each sample and their scaled variances) and to model the data set. Then, goodness-of-fit parameters could be calculated (mean total, class, and sample-wise explained variances, i.e. $r^{2}$ of original vs. modelled data $\times 100$; Dietze et al., 2012).

Radiocarbon dating was performed on plant macro remains by accelerator mass spectrometry (AMS) at the Poznan Radiocarbon Laboratory, Poland (1.5 SDH-Pelletron Model "Compact Carbon AMS"), for 10 samples of the Buor Khaya exposure profiles (Buo-02 and Buo-04), and at the CologneAMS laboratory, Germany (6 MV Tandetron), for 14 samples of the Buor Khaya drill core (BK-8). Samples were prepared using standard methods including acid-base-acid extraction with $1 \% \mathrm{HCl}$ and $1 \% \mathrm{NaOH}$. Extraction times with $\mathrm{HCl}$ and $\mathrm{NaOH}$ were reduced if the plant fragments were small and fragile to avoid sample destruction or loss. The clean and dry samples were combusted and the $\mathrm{CO}_{2}$ was converted into graphite (Rethemeyer et al., 2013). Conventional radiocarbon ages were calculated following the conventions defined by Stuiver and Polach (1977). Samples were 


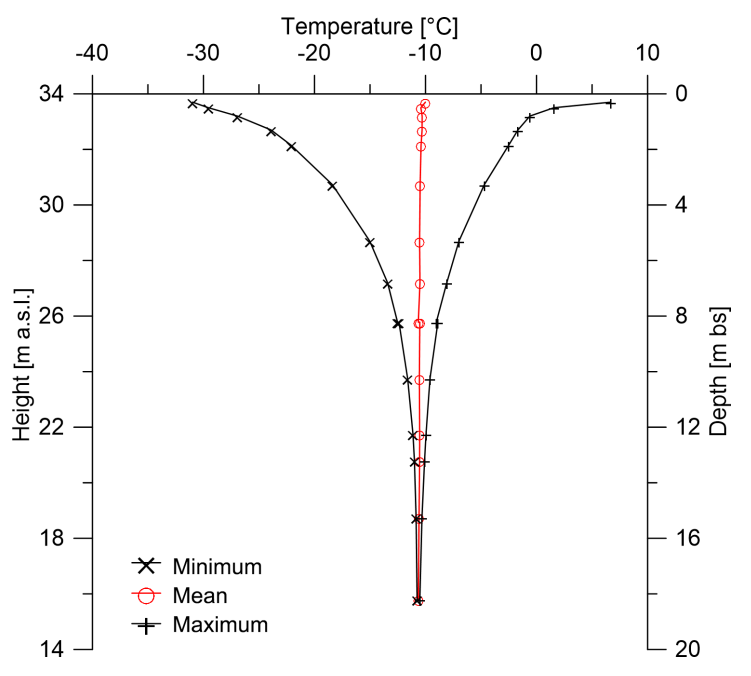

Figure 2. Minimum, mean (red), and maximum ground temperatures based on almost 3 years (from 11 May 2012 to 27 April 2015) of measurements made at $4 \mathrm{~h}$ intervals. Dashed lines show the approximate freezing temperature $\left(0{ }^{\circ} \mathrm{C}\right.$, vertical dashed line $)$ and summer thaw depth (active layer, horizontal dashed line). Sensor positions are shown by symbols in height above sea level (left axis) and depth relative to ground surface (right axis).

corrected for carbon contributions from exogenous sources using size-matched, radiocarbon-free material (coal), which was processed similar to the samples. Samples close to the limit of the radiocarbon method were blank corrected only (a) if the ${ }^{14} \mathrm{C}$ concentration (fraction modern - Fm) of the sample was larger than those of the corresponding process blank, and (b) if twice the error of the sample's Fm value was smaller than the sample Fm (Stuiver and Polach, 1977). Otherwise a minimum age is reported. The limiting age is calculated as $-8033 \times \ln (2 \sigma)$ because the $6 \mathrm{MV}$ AMS at Cologne produces lower blank values (due to its higher energy) compared to the Poznan laboratory. Conventional radiocarbon ages are reported in year before present (yr BP). Ages were calibrated using the Calib 7.0.2 software and the IntCal13 calibration curve (Reimer et al., 2013, used in conjunction with Stuiver and Reimer, 1993).

Three frozen segments of the drill core were separated for luminescence dating in order to determine sediment deposition ages (e.g. Aitken, 1998). Luminescence dating was applied because the method allows for dating of material beyond the limits of radiocarbon dating or evaluating results, when the radiocarbon method reaches the non-finite range of ages. The segments were taken from the lowermost part of the BK-8 drill core (with sample IDs referring to the sample depth in m b.s., BK-8_12.95-12.8, BK-8_16.55-16.25 m b.s., and BK-8_18.90-18.70). Under subdued light, the outer $2 \mathrm{~cm}$ layer of material was removed during controlled thawing to retrieve the inner core part that was not exposed to light during drilling and core preparation. The outer material was used for ice/water content measurements and high-purity Germa- nium (HPGe), low-level gamma spectrometry of the sediment's radionuclide content. The inner core part was processed for quartz and feldspar. The lack of pure extractable quartz and coarse-grain material $(>100 \mu \mathrm{m})$ required focusing on feldspar investigations. Target grain-size fractions were $20-40,40-63,63-100$, and $90-160 \mu \mathrm{m}$, but yields varied largely between samples with generally higher quantities of smaller grains. After the removal of carbonates (10\% $\mathrm{HCl})$ and organics $\left(30 \% \mathrm{H}_{2} \mathrm{O}_{2}\right)$ feldspar was separated from quartz using feldspar flotation $(0.2 \% \mathrm{HF}, \mathrm{pH} 2.4-2.7$, dodecylamine). Subsequently, density separation was performed to enrich K-feldspars with densities of $2.53-2.58 \mathrm{~g} \mathrm{~cm}^{-3}$. Although not mandatory, 40 min etching with $10 \% \mathrm{HF}$ was included for the coarser grains, while for grain-size fractions smaller than $100 \mu \mathrm{m}$, etching times were reduced by $5 \mathrm{~min}$ per size fraction to remove only the outer $10 \mu \mathrm{m}$ layer of individual grains.

Preparation of aliquots was done on aluminium discs of 4,2 , and $1 \mathrm{~mm}$ diameter, depending on the trade-off between small amounts of material and luminescence signal intensities. The infrared-stimulated luminescence (IRSL) of feldspars was measured using the TL/OSL DA-20 Reader (Bøtter-Jensen et al., 2003), equipped with a ${ }^{90} \mathrm{Sr}$ beta irradiation source $\left(4.95 \mathrm{~Gy} \mathrm{~min}^{-1}\right)$. Signal stimulation was performed at $870 \mathrm{~nm}$ with IR diodes $\left(125^{\circ} \mathrm{C}\right.$ for $\left.100 \mathrm{~s}\right)$. The feldspar luminescence emission was collected through a $410 \mathrm{~nm}$ optical interference filter to cut off scattered light from stimulation and was detected with a photomultiplier tube (Krbetschek et al., 1997). The measurement sequence followed the single-aliquot regenerative-dose (SAR) protocol according to Murray and Wintle (2000), including tests of dose recycling, recuperation, and correction for sensitivity changes. Appropriate measurement conditions were evaluated and adjusted based on preheat tests and dose-recovery tests (Murray and Wintle, 2003). Processing of measured data and statistical analyses were performed using Analyst v4.31.7 software (Duller, 2016) and the "Luminescence" R package for statistical computing version 0.6.4. (Kreutzer et al., 2012). The small data sets restricted age-model statistics to measures of central tendency. Therefore, the central age model (CAM) was used for palaeo-dose and IRSL age calculation (Galbraith et al., 1999).

The element (cation) content of ground ice was analysed by inductively coupled plasma optical emission spectrometry (ICP-OES; Perkin-Elmer Optima 3000 XL), while the anion content was determined by ion chromatography; Dionex DX-320). Hydrogen carbonate concentrations were measured by titration with $0.01 \mathrm{M} \mathrm{HCl}$ using an automatic titrator (Metrohm 794 Basic Titrino). Pore-water EC and pH were measured using a WTW MultiLab 540 multi-parameter device equipped with a TetraConTM 325 cell referenced to $20^{\circ} \mathrm{C}$ and a pH Sentix 43-1 electrode. The dissolved organic carbon (DOC) concentration in the sediment pore water was measured as non-purgeable organic carbon via catalytic combustion at $680^{\circ} \mathrm{C}$ using a Shimadzu TOC-VCPH instrument 

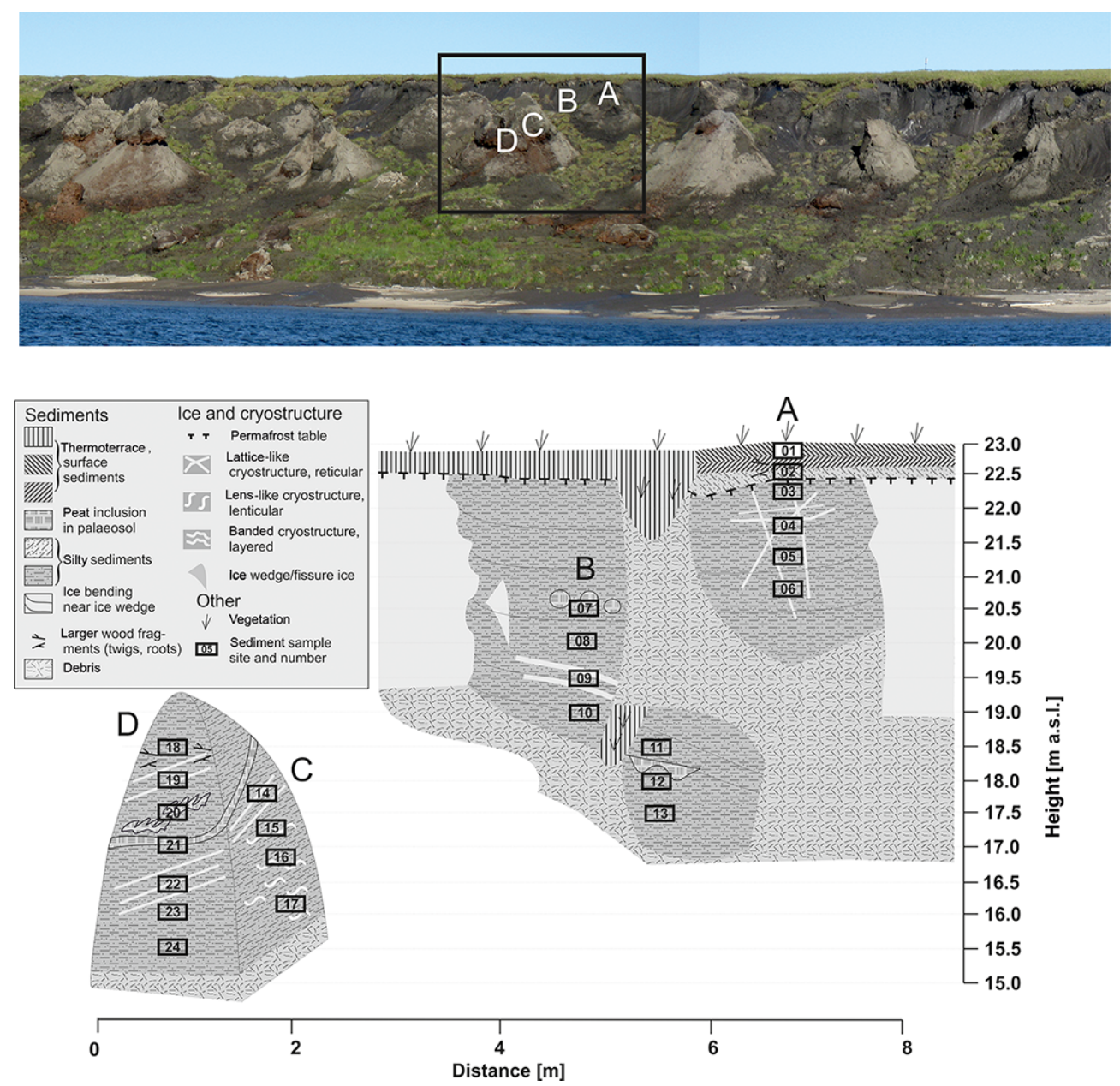

Figure 3. Overview photo and scheme of the Buo-02 Yedoma IC exposure with sample positions and main cryolithological features (modified from Strauss and Schirrmeister, 2011).

on samples treated with $20 \mu \mathrm{L}$ of $30 \%$ supra-pure $\mathrm{HCl}$. Stable isotopes of hydrogen $(\delta \mathrm{D})$ and oxygen $\left(\delta^{18} \mathrm{O}\right)$ were analysed on equilibrated samples using a Finnigan MAT Delta-S mass spectrometer following Meyer et al. (2000). Values are reported as per mille difference from the Vienna Standard Mean Ocean Water (VSMOW). Standard deviations were better than $0.5 \%$ for $\delta \mathrm{D}$ and $0.1 \%$ for $\delta^{18} \mathrm{O}$. The deuterium excess $(d$; Dansgaard, 1964) reflecting isotopic fractionation or exchange processes was calculated by $d=\delta \mathrm{D}-8 \delta^{18} \mathrm{O}$.

\section{Results}

\subsection{Ground temperature}

Ground temperatures measured at $4 \mathrm{~h}$ intervals for almost 3 years, from 11 May 2012 to 27 April 2015, ranged between -32 and $7{ }^{\circ} \mathrm{C}$, with a mean of approx. $-10^{\circ} \mathrm{C}$ (Fig. 2). The mean active-layer depth measured from borehole temperatures was less than $0.8 \mathrm{~m}$. The 3-year mean temperature vs. depth profile was relatively flat, with values below the active layer of $-10.6 \pm 0.2{ }^{\circ} \mathrm{C}$. The seasonal temperature amplitude decreased with depth to approx. $0.1{ }^{\circ} \mathrm{C}$ at the bottom of the borehole at $18.5 \mathrm{~m}$ b.s. According to the data of Romanovsky et al. (2010) our measured temperature is in line with the regional temperatures for Yedoma IC.

\subsection{Cryolithology, sedimentology, and soil properties}

\subsubsection{Buo-02}

Two composite profiles of Yedoma IC sections (Buo-02 and Buo-04) were studied in 2010 at coastal outcrops on the western shore of Buor Khaya Peninsula (Strauss and Schirrmeister, 2011). The Buo-02 profile extended approximately $10 \mathrm{~m}$ from the cliff edge down to a thermo-terrace where deeperlying permafrost deposits were buried by talus material (Fig. 3). Several 2-3 $\mathrm{m}$ wide and 5-7 $\mathrm{m}$ deep exposed ice wedges were present at a approx. $150 \mathrm{~m}$ wide thaw slump. The top of the Yedoma hill was marked with a trigonometric point (30.5 m a.s.1.) approximately $100 \mathrm{~m}$ away. 


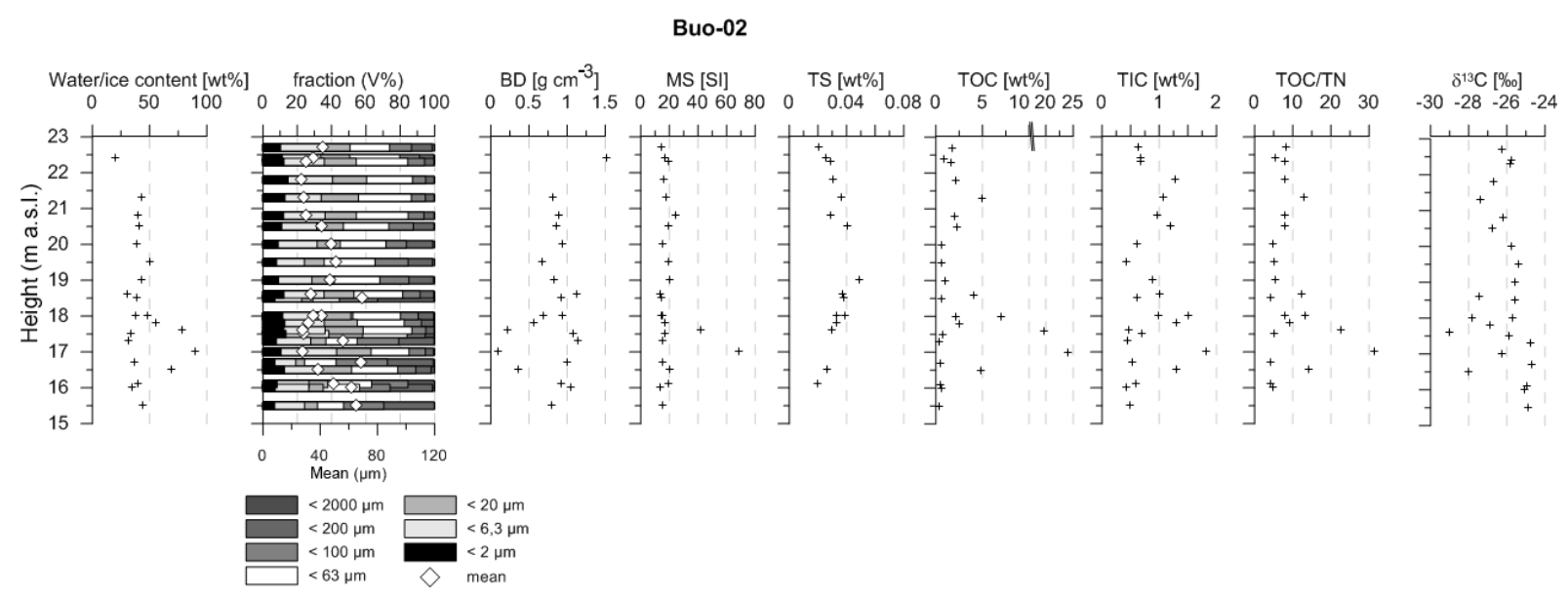

Figure 4. Soil and organic matter properties of the Buo-02 profile (note that due to overlapping sub-profiles, different values may be displayed at similar heights).

The composite Buo-02 profile started at $23 \mathrm{~m}$ a.s.l. and has four overlapping sub-profiles (A to D; Fig. 3). Summary of the characteristic sediment parameters are given in supporting online material (SOM 1; see Supplement). The active layer of Buo-02 was $0.7 \mathrm{~m}$ thick and was composed of brownish sand including recent roots. The lowermost part of the active layer at 22.7 to $22.3 \mathrm{~m}$ a.s.l. consisted of grey and silty sand with several larger plant fragments. Below the permafrost table, from 22.3 to $21.8 \mathrm{~m}$ a.s.l., the cryostructure of sub-profile A was horizontally banded $(<1 \mathrm{~cm}$ thick bands) and composed of densely layered ice lenses (SOM 2). Fine ice lenses and vertical veins were observed between the ice bands. The sediment was brownish-grey finesandy silt, with sporadic iron oxide patches. At $21 \mathrm{~m}$ a.s.l. larger organic patches occurred giving evidence for a cryoturbated palaeosol. The uppermost part of sub-profile B was marked by concentric organic-rich patches and plant detritus indicating another palaeo-cryosol horizon. Around these organic patches the sediment was composed of greybrown silts and fine-sandy silt containing vertical filament roots. The cryostructure was banded, especially visible at $19.5 \mathrm{~m}$ a.s.l. (SOM 2). In the lower part, lens-like to structureless cryostructures were found. Here at $18 \mathrm{~m}$ a.s.l., a palaeocryosol with tongues of light-brown material occurred. Subprofile $\mathrm{C}$ was composed of grey to brownish silty fine sand. The uppermost sample was ice-saturated with ice veins up to $10 \mathrm{~mm}$ thick. At the underlying parts down to $16.1 \mathrm{~m}$ a.s.l., the cryostructures were coarse-to-fine lens-like (SOM 2). In sub-profile D, a remarkable heterogeneity of sediment composition was observed. In the upper part at $18.5 \mathrm{~m}$ a.s.l. the sediment was composed of greyish silt with brown patches and larger plant fragments. From 17.5 to $17 \mathrm{~m}$ a.s.l., a peat layer and peat inclusions appeared, along with vertical and diagonal ice veins. Below the peat layer, the sediment consisted of brownish silty sand with several plant fragments.
The cryostructure was micro-lens-like with some ice veins (SOM 2).

The measured absolute ice contents varied between 20 and $90 \mathrm{wt} \%$ (Fig. 4); ice oversaturation was connected to organic-rich palaeo-cryosol horizons. The grain-size distributions were dominated by fine $(18-32 \%)$, medium (5$22 \%)$, and coarse $(15-31 \%)$ silt with a clay component (7-14\%), and fine (8-30\%), medium (5-30\%), and small coarse $(0.1-1.4 \%)$ sand fractions. The mean grain size varied between 26.6 and $69.9 \mu \mathrm{m}$ (Fig. 4). Five robust grainsize end-members (rEM1 to 5) that explain $80.6 \%$ of the total grain-size variability in the Buo- 02 profile had main modes in the clay to very fine silt $(4.7 \mu \mathrm{m}, \mathrm{rEM} 1)$, medium to coarse silt $(30 \mu \mathrm{m}, \mathrm{rEM} 2)$, coarse silt to very fine sand (58 $\mu \mathrm{m}, \mathrm{rEM} 3)$, very fine sand $(111 \mu \mathrm{m}, \mathrm{rEM} 4)$, and fine sand $(177 \mu \mathrm{m}, \mathrm{rEM} 5)$ (Table 1). The profile was dominated by medium to coarse silt (rEM2) and very fine sand (rEM4), which explained 43 and $38 \%$ of the variability, respectively; rEM1, 3, and 5 explained the remaining $19 \%$ of variability.

Bulk density (BD) values varied around $1 \mathrm{~g} \mathrm{~cm}^{-3}$; however, the lowest values of $0.1 \mathrm{~g} \mathrm{~cm}^{-3}$ were associated with the palaeo-cryosol horizons described above. Mass-specific MS value range between 13.7 and 24.5 SI except for two samples of the palaeo-cryosol horizon in sub-profile D (42 and $68 \mathrm{SI}$ ). The biogeochemical records of the Buo-02 sequence (Fig. 4) varied strongly, with TOC values between 0.3 and $24 \mathrm{wt} \%$, TIC values between 0.4 and $1.8 \mathrm{wt} \%$, TOC / TN ratios of 4.1 to 22.7 , and $\delta^{13} \mathrm{C}$ values between -29 and $-24.7 \%$. The TS values were low, between 0.02 and $0.05 \mathrm{wt} \%$.

\subsubsection{Buo-04}

The second composite profile Buo-04 was a $15 \mathrm{~m}$ long sequence, which was surveyed downwards starting in front of a steep wall at the cliff edge, crossing the thermo-terrace, and ending at a large thermokarst mound at beach level (Fig. 5). 
Table 1. Comparison of robust grain-size end-members, their explained variances of scores, and performance of original vs. modelled data (using the mean robust end-members, $R^{2} \times 100$ ).

\begin{tabular}{lrrrrr|rrrrrr|rrr}
\hline & \multicolumn{4}{c}{ Main mode $[\mu \mathrm{m}]$} & \multicolumn{4}{c|}{$\begin{array}{c}\text { Mean explained variances } \\
\text { (scores, \%) }\end{array}$} & \multicolumn{2}{c}{$\begin{array}{c}\text { Mean explained variances } \\
\text { (original vs. model, \%) }\end{array}$} \\
\cline { 2 - 14 } rEM & 1 & 2 & 3 & 4 & 5 & 1 & 2 & 3 & 4 & 5 & Classes & Samples & Total \\
\hline Buo-02 & 4.7 & 30.1 & 57.8 & 111.0 & 176.8 & 6.4 & 42.9 & 7.4 & 38 & 5.2 & 78.9 & 82.3 & 80.6 \\
Buo-04 & 4.7 & 25.0 & 76.4 & & & 9.3 & 42.7 & 48 & & & 66.8 & 80.6 & 73.7 \\
BK-8 & 2.9 & 25.0 & 76.4 & 213.2 & & 16.2 & 32.9 & 7.1 & 43.7 & & 75.0 & 73.1 & 74.1 \\
\hline
\end{tabular}

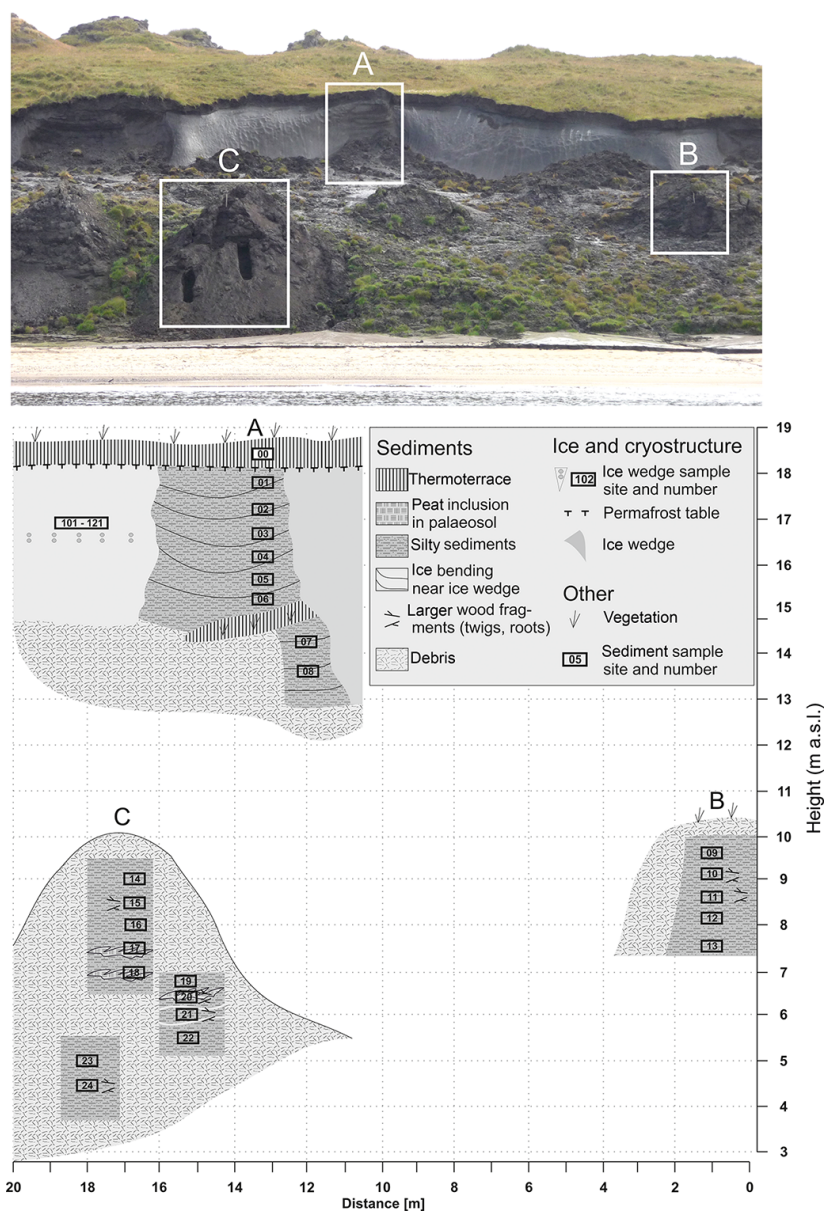

Figure 5. Overview photo and scheme of the Buo-04 Yedoma IC exposure with sample positions and main cryolithological features (modified from Strauss and Schirrmeister, 2011).

Sub-profiles from two thermokarst mounds overlapped. The uppermost sub-profile A (18.5 to $13.6 \mathrm{~m}$ a.s.l.) was exposed at a steep wall between two longitudinal cut-ice wedges. A summary of the characteristic sediment parameters is given in SOM 1. The uppermost sample was taken from the active layer in the zone of modern vegetation and roots. The frozen deposits consisted of greyish-brown silty fine sand with a lens-like cryostructure and with horizontal ice bands in several parts. The sediments and the ice bands bent on both sides towards the ice wedges. The nearby studied syngenetic ice wedge was diagonally cut by the exposure wall (10 $\mathrm{m}$ apparent width). Here, 21 ice-wedge samples were taken at $0.5 \mathrm{~m}$ intervals (SOM 3 ). The light-grey ice wedge contained gas bubbles and several $\mathrm{mm}$ wide vertical sediment stripes. Sub-profile B (10.0 to $7.6 \mathrm{~m}$ a.s.1.) consisted of greyish-brown silty fine-grained sand. The cryostructure was layered with ice bands $<2 \mathrm{~mm}$ thick. Between the ice bands, horizontally oriented ice lenses occurred (SOM 3). Coarse plant and wood fragments were visible at $9 \mathrm{~m}$ a.s.l. The lowermost thermokarst mound (sub-profile C) was sampled in three places (SOM 3). The uppermost part of sub-profile C between 9 and $7 \mathrm{~m}$ a.s.l. was characterized by greyish-brown silty fine-grained sand and the occurrence of plant detritus, much root material, and smaller plant stems. At $8.5 \mathrm{~m}$ a.s.l. coarse lens-like ice bands occurred. These bands appeared at $5 \mathrm{~cm}$ intervals and ice lenses $(<1 \mathrm{~mm}$ thick and 0.5 to $1 \mathrm{~cm}$ long) in the sediment interlayers were reticular oriented. At $8 \mathrm{~m}$ a.s.l., a matrix of greyish-brown silty fine sand contained a peaty cryoturbated palaeosol. Plant detritus was layered at $7 \mathrm{~m}$ a.s.l. The sediment in the middle part of sub-profile $\mathrm{C}$ between 6.8 and $5.5 \mathrm{~m}$ a.s.l. became sandier with depth. The peaty-bedded and horizontally bedded layers continued. In addition, coarse plant and wood fragments were found at 6.5 to $6.0 \mathrm{~m}$ a.s.l. At $6.8 \mathrm{~m}$ a.s.l., the deposits were ice supersaturated and the cryostructure was composed of coarse ice lenses surrounding plant fragments. Ice bands less than 0.5 to $4 \mathrm{~mm}$ thickness occurred. The lowest part of sub-profile $\mathrm{C}$ (5 to $4 \mathrm{~m}$ a.s.l.) was sandier and drier. Here a yellowish lightgrey matrix with iron oxide spots and broken ice lenses as well as horizontal ice fissures indicated a disturbance of the deposits (SOM 3).

The absolute ice contents of the Buo-04 sequence varied between 22 and $59 \mathrm{wt} \%$. The grain-size distribution was again dominated by fine (10-25\%), medium (7-25\%), and coarse $(26-41 \%)$ silt fractions and a clay component (6$14 \%)$. The sand contents were low (4-10 wt \%) in the uppermost sub-profile A (18.5 to $13.6 \mathrm{~m}$ a.s.1.) but similar to the Buo-02 sequence (21-43 wt \%) in the B and C sub-profiles (9.6 to $4.3 \mathrm{~m}$ a.s.l.). This was also mirrored in the mean grainsize values between 21.2 and $27.5 \mu \mathrm{m}$ in sub-profile $\mathrm{A}$ and 33.6 and $54.4 \mu \mathrm{m}$ in sub-profiles B and C. Three rEMs de- 


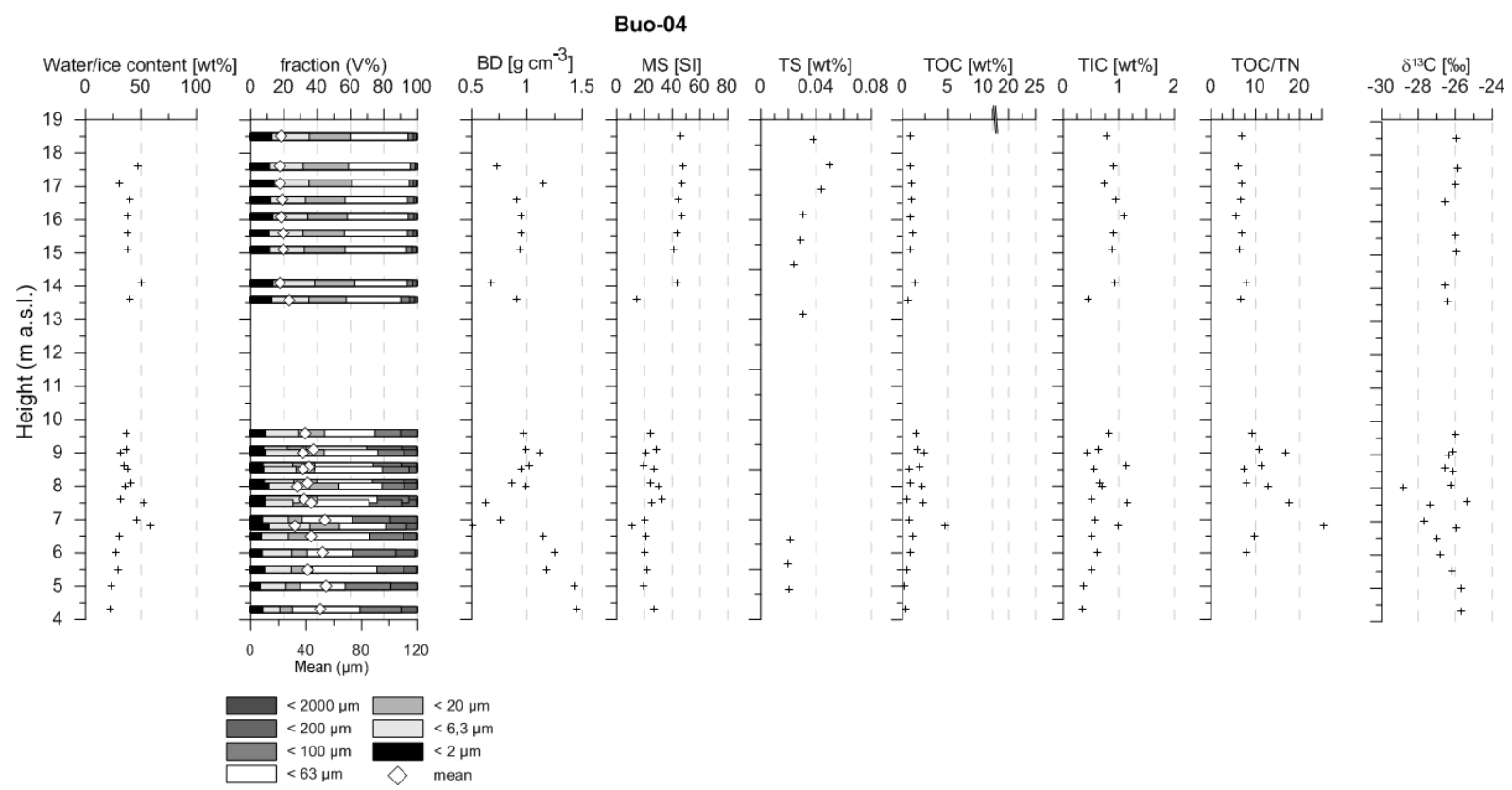

Figure 6. Soil and organic matter properties of the Buo-04 profile (note that due to overlapping sub-profiles, different values may be displayed at similar heights).

scribe $73.7 \%$ of the grain-size distributions of the Buo-04 sequence (Table 1). The clay to very-fine silt rEM1 (main mode at $4.7 \mu \mathrm{m}$ as in Buo-02) accounts only for $9 \%$ of the variance in the grain-size data set. The medium silt rEM2 (main mode at $25 \mu \mathrm{m}$ ) explains $43 \%$ and the very fine sandy rEM3 (main mode at $76 \mu \mathrm{m}$ ) accounts for $48 \%$ of the explainable grain-size variance.

$\mathrm{BD}$ values varied between 0.5 and $1.5 \mathrm{~g} \mathrm{~cm}^{-3}$ with increasing values in the lowermost part. The MS values were relatively high in sub-profile A (41.1-47.7 SI) except for the lowermost sample at $13.6 \mathrm{~m}(14.3 \mathrm{SI})$, which is the lowest value of the entire record. The other parts were characterized by little variation between 20 and 30 SI. The Buo-04 sequence showed TOC values from 0.2 to $4.7 \mathrm{wt} \%$, TIC values from 0.3 to $1.1 \mathrm{wt} \%$ (both lower than in Buo-02), TOC / TN ratios from 5.6 to 25.3 , and $\delta^{13} \mathrm{C}$ values between -28.8 and $-25.4 \%$. The TS values varied between 0.02 and $0.05 \mathrm{wt} \%$. Higher TOC contents and TOC / TN ratios as well as the lowest $\delta^{13} \mathrm{C}$ values were associated with the occurrence of a palaeo-cryosol horizon around 6 to $8 \mathrm{~m}$ a.s.l.

\subsubsection{BK-8}

According to a detailed cryolithological description (SOM 4 and 5), the BK-8 core was sub-divided in the field into five segments completed by a sixth segment characterized by specific pore-water composition (Fig. 7). Characteristic sediment parameters are summarized in SOM 1. The active layer (0-0.35 $\mathrm{m}$ b.s., $34-33.65 \mathrm{~m}$ a.s.l.) is the uppermost core segment consisting of brown silty fine-grained sand with plant remains and roots. Segregated ice was characterized by irreg-

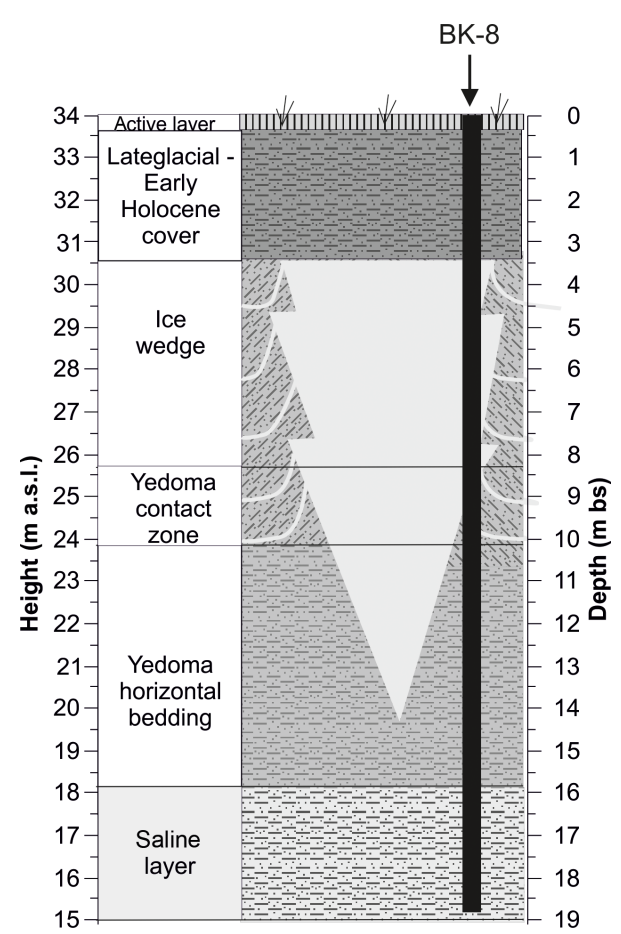

Figure 7. Scheme of the BK-8 permafrost core including the main cryolithological units. The legend is given in Figs. 3 and 5.

ular, partly transverse-diagonally and horizontally arranged micro-, fine, and coarse lens-like cryostructures. The second segment (0.35-3.4 m b.s., 33.65-30.6 m a.s.1.) contained grey-brown silty fine-grained sand, plant remains, and woody 

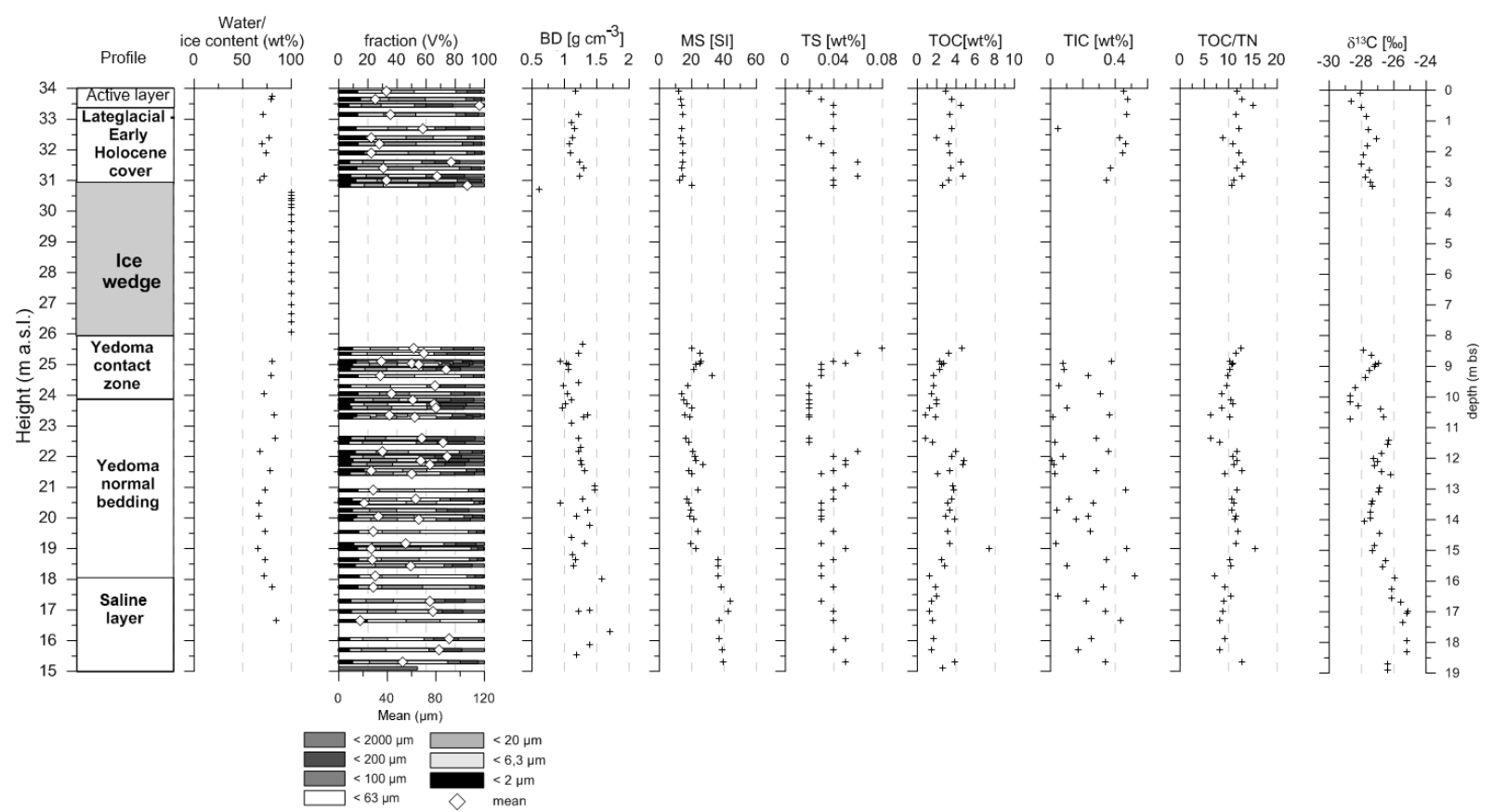

Figure 8. Soil and organic matter properties of the BK-8 Yedoma IC core.

fragments (twigs, roots). The cryostructure was coarse irregular lens-like. Sub-vertical ice veins $(1-5 \mathrm{~mm}$ wide, 10 $15 \mathrm{~cm}$ long) occurred. Between 3.4 and $8.35 \mathrm{mb}$ b.s. (30.6$25.65 \mathrm{~m}$ a.s.1.) the core cut an ice wedge of clear colourless ice with gas bubbles $<1 \mathrm{~mm}$ in diameter and paralleloriented vertical sediment stripes up to $5 \mathrm{~mm}$ thick. The fourth segment (8.35-9.95 m b.s., 25.65-24.05 $\mathrm{m}$ a.s.l.) represented the contact zone between the ice wedge and the sediment, and was composed of grey-brown silty fine-grained sand and plant remains with a diagonal coarse lens-like cryostructure and several upturned ice bands. The fifth segment (9.95-16.0 m b.s., 23.85-18.0 $\mathrm{m}$ a.s.1.) consisted of horizontally bedded grey-brown silty fine-grained sand, mostly with only a few plant remains. In several layers, larger $(\sim 5 \mathrm{~mm})$ woody plant fragments occurred, coated by ice crusts. The cryostructure showed horizontal alternations of fine lens-like reticulated and coarse lens-like reticulated interlayers and centimetre-thick ice bands. The sixth segment (16.25-18.9 m b.s.; 17.75.-15.1 m a.s.1.) is a part of segment five visible only in the hydrochemical data and will be described more detailed in Sect. 4.4.

The absolute ice contents of the BK- 8 core varied between 66 and $84 \mathrm{wt} \%$ (Fig. 8). The grain-size distribution was relatively uniform, dominated by fine (12-20\%), medium (11$24 \%)$, and coarse $(23-33 \%)$ silt and containing clay (9$15 \%)$, fine-sand $(5-15.8 \%)$, medium-sand $(7-20 \%)$, and a small fraction of coarse-sand (1-8\%) components. The mean grain size varied between 31.2 and $73.6 \mu \mathrm{m}$. Four rEMs were found and account for $74.1 \%$ of the variability in the BK-8 grain-size data (Table 1): a clay rEM1 (main mode at $2.7 \mu \mathrm{m}$ ), a medium-silt rEM2 (main mode at $25 \mu \mathrm{m}$ ), a very finegrained sand rEM3 (main mode at $76 \mu \mathrm{m}$ ), and a fine-grained sand rEM4 (main mode at $213 \mu \mathrm{m}$ ) explained 16, 33, 7, and $44 \%$ of the variance in the grain-size data, respectively.

BD values varied between 0.6 and $1.6 \mathrm{~g} \mathrm{~cm}^{-3}$, without a clear trend along the core, while MS values (12-38 SI) increased with depth. In general, the biogeochemical data are in a similar range as that from the Buo-02 and Buo-04 exposure sequences with TOC contents between 0.8 and $7.4 \mathrm{wt} \%$, TIC contents between 0.2 and $0.5 \mathrm{wt} \%$, TOC / TN ratios of 6.3 to 15.6 , and $\delta^{13} \mathrm{C}$ values between -28.8 and $-25.4 \%$. The TS values vary between 0.02 and $0.08 \mathrm{wt} \%$.

\subsection{Dating}

Radiocarbon dates were obtained from five Buo-02 profile samples between 16 and $22.3 \mathrm{~m}$ a.s.l., and ranged between $45.0 \pm 2$ and $30.1 \pm 0.3 \mathrm{kyr}$ BP (Table 2). Five samples (between 6.8 and $17.1 \mathrm{~m}$ a.s.l.) from the lower-lying Buo-04 profile had mostly non-finite ages and an uppermost sample had an age of $49.0 \pm 3 \mathrm{kyr}$ BP. Both profiles showed deposition of the Yedoma IC during interstadial MIS3.

Samples were selected from the BK-8 14 drill core for radiocarbon dating, including four plant fragments and OM samples that were isolated from the ice wedge (Table 2). The five ages from above the ice wedge between 3.35 and $0.3 \mathrm{~m}$ b.s. (30.65 and $33.7 \mathrm{~m}$ a.s.l.) covered the late-glacial period with ages of $11.4 \pm 0.05$ to $9.7 \pm 0.05 \mathrm{kyr}$ BP. The four ages from the ice wedge showed a broad range, between $22.1 \pm 0.1$ and $5.1 \pm 0.05 \mathrm{kyr}$ BP. The youngest age can be considered as contamination during the drilling pro- 
Table 2. Radiocarbon dating on plant macro remains (and two sediment samples containing plant remains: COL2945 and COL2796). Calibrations were done using Calib 7.0.2 and the IntCal13 curve (Reimer et al., 2013). Ranges marked with a $*$ are suspect due to impingement on the end of the calibration data set. Depth is given in metres below surface level ( $\mathrm{m}$ b.s.l.) and height in metres above sea level (m a.s.l.). Poz: Poznan Radiocarbon Laboratory, Poland; COL: CologneAMS, Germany. The bold marked samples are from the ice wedge in BK-8.

\begin{tabular}{|c|c|c|c|c|c|c|}
\hline Lab. ID & Sample ID & $\begin{array}{r}\text { Depth } \\
\text { [m b.s.l] }\end{array}$ & $\begin{array}{r}\text { Height } \\
\text { [m a.s.1.] }\end{array}$ & $\begin{array}{r}\text { Radiocarbon ages } \\
{[\mathrm{yr} \mathrm{BP}]}\end{array}$ & $\begin{array}{r} \pm \\
{[\mathrm{yr}]}\end{array}$ & $\begin{array}{l}\text { Calibrated ages }(2 \sigma) \\
{[\text { cal yr BP] }}\end{array}$ \\
\hline Poz-42074 & Buo-02-A-03 & 0.7 & 22.3 & 30100 & 300 & $33691-34683$ \\
\hline Poz-42075 & Buo-02-B-09 & 3.5 & 19.5 & 34700 & 600 & $37896-40490$ \\
\hline Poz-42076 & Buo-02-B-12 & 5 & 18 & 41500 & 1500 & $42511-47838$ \\
\hline Poz-42077 & Buo-02-D-20 & 5.5 & 17.5 & 45000 & 2000 & $45004-50000 *$ \\
\hline Poz-42078 & Buo-02-D-23 & 7 & 16 & 43000 & 1500 & $43726-49404$ \\
\hline Poz-42081 & Buo-04-A-02 & 1.5 & 17.1 & 49000 & 3000 & \\
\hline Poz-42082 & Buo-04-A-08 & 5 & 13.6 & $>48000$ & & \\
\hline Poz-42083 & Buo-04-B-10 & 8.5 & 9.1 & $>55000$ & & \\
\hline Poz-42084 & Buo-04-C-16 & 10.5 & 8 & $>49000$ & & \\
\hline Poz-42085 & Buo-04-C-20 & 11.7 & 6.8 & $>55000$ & & \\
\hline COL2790.1.1 & BK-8-0.25-0.35 m & 0.3 & 33.7 & 9700 & 50 & $11068-11231$ \\
\hline COL2791.1.1 & BK-8-0.55-0.85 m & 0.7 & 33.3 & 10149 & 50 & $11603-12048$ \\
\hline COL2792.1.1 & BK-8-1.60-1.80m & 1.7 & 32.3 & 11100 & 50 & $12818-13078$ \\
\hline COL2793.1.1 & BK-8-2.4-2.6m & 2.5 & 31.5 & 11200 & 50 & $12670-13175$ \\
\hline COL2794.1.1 & BK-8-2.85-3.00 m & 2.93 & 31.07 & 11400 & 50 & $13116-13351$ \\
\hline COL2943.2.1 & BK-8. 3.30-3.40 m & 3.35 & 30.65 & 5100 & 50 & 5723-5939 \\
\hline COL2944.1.1 & BK-8. $>4.35 \mathrm{~m}$ & $\sim 4.35$ & $\sim 29.65$ & 16800 & 60 & $20055-20474$ \\
\hline COL2945.1.1 & BK-8. $>7.95 \mathrm{~m}$ & $\sim 7.95$ & $\sim 26.05$ & 22100 & 100 & $26041-26599$ \\
\hline COL2946.1.1 & BK-8. $8.35 \mathrm{~m}$ & 8.35 & 25.65 & 14700 & 60 & 17 687-18 066 \\
\hline COL2795.1.1 & BK-8-8.75-8.90 m & 8.83 & 25.17 & 53500 & 800 & \\
\hline COL2796.1.1 & BK-8-10.40-10.65 m & 10.53 & 23.47 & 50300 & 2100 & \\
\hline COL2797.1.1 & BK-8-10.90-11.40 m & 11.15 & 22.85 & 54100 & 3400 & \\
\hline COL2798.1.1 & BK-8-12.95-13.10 m & 13.03 & 20.97 & 51200 & 700 & \\
\hline COL2799.1.1 & BK-8-16.00-16.25 m & 16.13 & 17.87 & 52700 & 800 & \\
\hline
\end{tabular}

cess, due to input of younger material from below. Five ages obtained from below the ice wedge, between 16.1 and $8.8 \mathrm{~m}$ b.s. (17.9 and $25.2 \mathrm{~m}$ a.s.l.), ranged between $54.1 \pm 3.4$ and $50.3 \pm 2.1 \mathrm{kyr} B$ P.

The Yedoma IC below the ice wedge was dated by IRSL at three depths: $12.95-12.8,16.55-16.2$, and $18.9-18.7 \mathrm{~m}$ b.s. The dating results for different grain-size fractions are summarized in Table 3. Applying the CAM, the deposition ages of the $12.95-12.8 \mathrm{~m}$ b.s. core interval are $46.1 \pm 3.5$, $44.2 \pm 3.6$, and $45.4 \pm 4.8 \mathrm{kyr}$ as obtained from different available grain-size fractions of $63-100,40-63$, and 20 $40 \mu \mathrm{m}$, respectively. The $16.55-16.2 \mathrm{~m}$ b.s. core interval has an age of $44.2 \pm 3.3 \mathrm{kyr}$ (from the $90-160 \mu \mathrm{m}$ grain-size fraction only). The lowermost IRSL-dated $18.9-18.7 \mathrm{~m}$ b.s. core interval provided grain-size fractions of 90-160, 63-100, and 40-63 $\mu \mathrm{m}$, yielding ages of $45.6 \pm 5.5,45.9 \pm 3.5$, and $51.1 \pm 4.9 \mathrm{kyr}$, respectively. Only low aliquot numbers were available in sample BK-8, i.e. $12.95-12.8 \mathrm{~m}$ b.s. in the $63-$ 100 and $20-40 \mu \mathrm{m}$ fractions as well as in the $18.9-18.7 \mathrm{~m}$ b.s. $90-160 \mu \mathrm{m}$ fraction sample. Therefore, the estimated age information from these analyses is of lower probability. However, the overlapping age ranges in both samples where dif- ferent grain-size fractions were dated show a general agreement of all ages in the samples. The deduced deposition age ranges are 47.8 to $40.6 \mathrm{kyr}$ for BK-8 $12.95-12.8 \mathrm{~m}$ b.s., 47.5 to $40.9 \mathrm{kyr}$ for BK-8 $15.55-15.2 \mathrm{~m}$ b.s., and 56.0 to $42.4 \mathrm{kyr}$ for BK-8 18.9-18.7 m b.s.

\subsection{Hydrochemistry, stable water isotopes}

Stable isotope ratios of Buo- 02 pore ice ranged between -27.9 and $-19.6 \%$ for $\delta^{18} \mathrm{O}$ and -220.4 and $-166.0 \%$ for $\delta \mathrm{D}$, and $d$-excess values between approx. -14.1 and $15.4 \%$ o (Fig. 9). The EC varied between 550 and $3500 \mu \mathrm{S} \mathrm{cm}^{-1}$. DOC concentrations lie below $400 \mathrm{mg} \mathrm{L}^{-1}$ except for three samples with high values up to $1272 \mathrm{mg} \mathrm{L}^{-1}$. The $\mathrm{pH}$ was slightly basic and generally trended from over 8 near the top of the profile to values below 8 at the bottom.

Stable Buo-04 pore ice isotope ratios showed a trend from lower values (around $-32.5 \%$ or for $\delta^{18} \mathrm{O}$ and $-241.8 \%$ o $\delta \mathrm{D}$ ) to higher values $\left(-20.4 \%\right.$ for $\delta^{18} \mathrm{O}$ and $\left.-155.9 \% \circ \delta \mathrm{D}\right)$ with depth (Fig. 10). Variable $d$-excess values ranged between -3.9 and $22.5 \%$ o. EC showed an inverse trend with height, from high values of almost $2400 \mu \mathrm{S} \mathrm{cm}^{-1}$ at the upper end of 
Table 3. Results of IRSL dating from three BK- 8 core samples using different feldspar grains on 4 mm aliquots ( $n$ : number of aliquots; CAM: central age model; see Galbraith et al., 1999), samples with interpreted age information are highlighted in bold.

\begin{tabular}{|c|c|c|c|c|c|c|c|c|c|c|}
\hline ID & $\begin{array}{r}\text { Depth } \\
\text { [mb.s.1] }\end{array}$ & $\begin{array}{r}\text { Height } \\
\text { [m a.s.1.] }\end{array}$ & $\begin{array}{r}\text { Grain-size } \\
\text { fraction }[\mu \mathrm{m}]\end{array}$ & $n$ & $\begin{array}{r}\text { Mean } \\
\text { palaeo-dose }[\mathrm{Gy}]\end{array}$ & $\begin{array}{r}\text { Standard } \\
\text { deviation [\%] }\end{array}$ & $\begin{array}{r}\text { Mean dose rate } \\
{\left[\mathrm{Gy} \mathrm{kyr}^{-1}\right]}\end{array}$ & $\begin{array}{r}\text { CAM } \\
{[\mathrm{Gy}]}\end{array}$ & $\begin{array}{r}\text { Overdis- } \\
\text { persation [\%] }\end{array}$ & $\begin{array}{r}\text { Age } \\
{[\mathrm{kyr}]}\end{array}$ \\
\hline BK-8 & $12.95-12.8$ & $21.05-21.20$ & $63-100$ & 5 & $89.4 \pm 3.5$ & 8.8 & 1.9 & $89.4 \pm 3.2$ & 5.0 & $46.1 \pm 3.5$ \\
\hline BK-8 & $12.95-12.8$ & $21.05-21.20$ & $40-63$ & 15 & $85.2 \pm 4.3$ & 19.5 & 1.8 & $81.4 \pm 3.4$ & 11.8 & $44.2 \pm 3.6$ \\
\hline BK-8 & $12.95-12.8$ & $21.05-21.20$ & $20-40$ & 5 & $119.7 \pm 20.4$ & 38.1 & 1.9 & $112.0 \pm 16.0$ & 31.3 & $45.4 \pm 4.8$ \\
\hline BK-8 & $16.55-16.2$ & 17.45-17.7 & $90-160$ & 27 & $108.9 \pm 4.0$ & 19 & 2.4 & $104.5 \pm 3.5$ & 12.0 & $44.2 \pm 3.3$ \\
\hline BK-8 & $18.9-18.7$ & $15.1-15.3$ & $90-160$ & 8 & $108.8 \pm 10.0$ & 26.0 & 2.3 & $103.1 \pm 10.0$ & 23.7 & $45.6 \pm 5.5$ \\
\hline BK-8 & $18.9-18.7$ & $15.1-15.3$ & $63-100$ & 32 & $98.1 \pm 2.4$ & 13.8 & 2.1 & $96.3 \pm 2.2$ & 8.8 & $45.9 \pm 3.5$ \\
\hline BK-8 & $18.9-18.7$ & $15.1-15.3$ & $40-63$ & 14 & $108.5 \pm 7.0$ & 24.2 & 2.0 & $103.9 \pm 6.0$ & 2.0 & $51.1 \pm 4.9$ \\
\hline
\end{tabular}

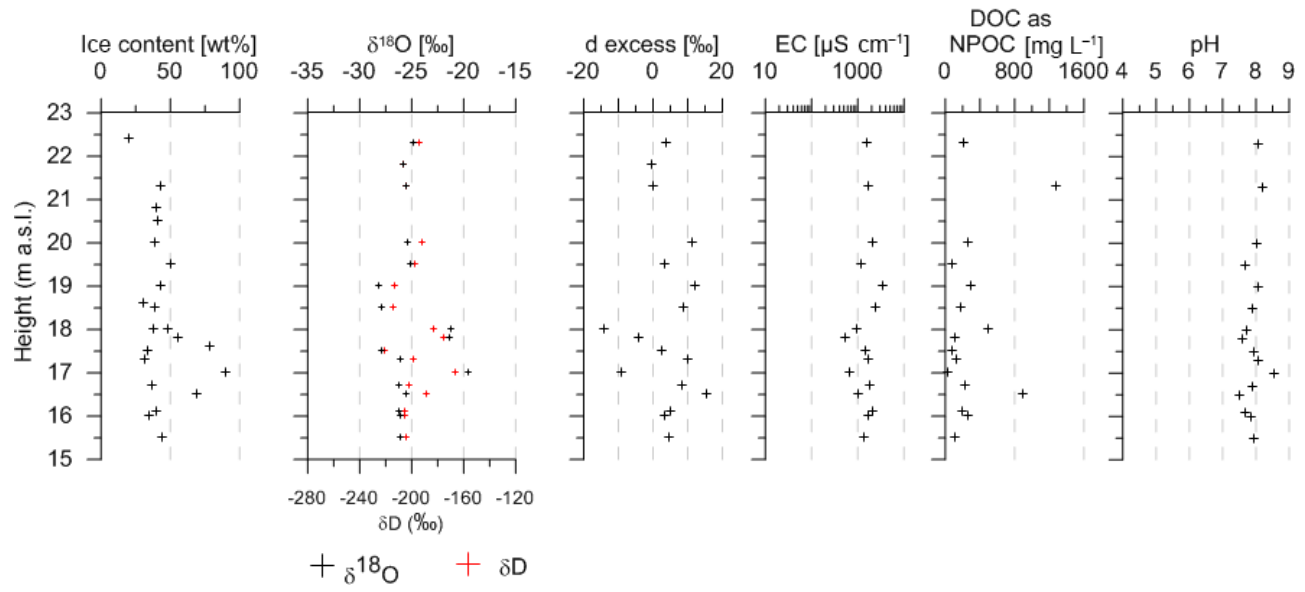

Figure 9. Measurements of ice content, isotope ratios, electrical conductivity (EC), $\mathrm{pH}$, and solutes over height in ma.s.l. for samples from the Buo-02 exposure.

the profile to $200 \mu \mathrm{S} \mathrm{cm}^{-1}$ at the bottom. The $\mathrm{pH}$ was slightly basic (7.5 to 8.2). DOC values, except for one data point, were below $200 \mathrm{mg} \mathrm{L}^{-1}$.

The pore-space solution from the BK-8 core showed considerable hydrochemical variability with depth (Fig. 11). Stable isotope ratios were the highest in the active layer, and were lower and decreased in the late-glacial-early Holocene cover above the ice wedge. Isotope ratios in the ice wedge were lower $\left(\delta^{18} \mathrm{O}-31.2\right.$ to $-31.9 \%$ o $)$ than values in the underlying Yedoma IC; the latter exceeded -28.5 and $-215.8 \%$ between 17.5 and $25.6 \mathrm{~m}$ a.s.1. At the bottom of the core, however, isotope ratios declined from $17.5 \mathrm{~m}\left(\delta^{18} \mathrm{O}\right.$ $-28.5 \%$ ) down to their lowest values at $15.5 \mathrm{~m}$ a.s.1. $\left(\delta^{18} \mathrm{O}\right.$ $-34.6 \%$ ). This coincided with increasing $d$-excess values, up to almost $23.6 \%$. The pore solution EC lie between 100 and $1000 \mu \mathrm{S} \mathrm{cm}^{-1}$ (approx. $70-360 \mathrm{mg} \mathrm{L}^{-1}$ by summing major ion concentrations) in sediment above the ice wedge. The ice wedge was relatively pure, with $\mathrm{EC}<100 \mu \mathrm{S} \mathrm{cm}^{-1}$. Below the ice wedge, the pore-space solution EC ranged from $>500$ to $4000 \mu \mathrm{S} \mathrm{cm}^{-1}$ (approx. > $140-1600 \mathrm{mg} \mathrm{L}^{-1}$ ). The ECs in the bottom portion of the core, corresponding to the depths at which lower stable isotope ratios were observed, were high, between 7000 and $14000 \mu \mathrm{S} \mathrm{cm}^{-1}$ (ap- prox. $3600-7700 \mathrm{mg} \mathrm{L}^{-1}$ ). DOC concentrations were generally below $400 \mathrm{mg} \mathrm{L}^{-1}$, except for most samples between 19 and $23 \mathrm{~m}$ a.s.l., some of which had DOC concentrations in excess of $1000 \mathrm{mg} \mathrm{L}^{-1}$. The solution $\mathrm{pH}$ was between 5 (active layer, around $21 \mathrm{~m}$ a.s.l.) and 8 , but most samples were basic. Solute concentrations followed the EC.

Anion concentrations in the active layer and the lateglacial-early Holocene cover were dominated by $\mathrm{Cl}^{-}$and $\mathrm{SO}_{4}^{2-}$, the latter particularly at the transition from lateglacial-early Holocene cover to ice wedge. Measurable $\mathrm{NO}_{3}^{-}$ concentrations were observed only in the uppermost two samples of the active layer. Cation concentrations over the same depths were the highest for $\mathrm{Na}^{+}\left(7-40 \mathrm{mg} \mathrm{L}^{-1}\right)$ and $\mathrm{Ca}^{2+}\left(6-80 \mathrm{mg} \mathrm{L}^{-1}\right)$, with maxima and minima associated with the active layer or the transition to the underlying ice wedge. All solute concentrations in the ice wedge were less than $10 \mathrm{mg} \mathrm{L}^{-1}$. Immediately below the ice wedge (below $26 \mathrm{~m}$ a.s.l.), concentrations of $\mathrm{Cl}$ and $\mathrm{Na}$ were all high, with variation over 1-2 orders of magnitude with height. Below $18 \mathrm{~m}$ a.s.l., concentrations of a number of solutes increased markedly by another order of magnitude: $\mathrm{Cl}$ (over $4 \mathrm{gL}^{-1}$ ) and $\mathrm{Na}$ (up to $960 \mathrm{mg} \mathrm{L}^{-1}$ ). 


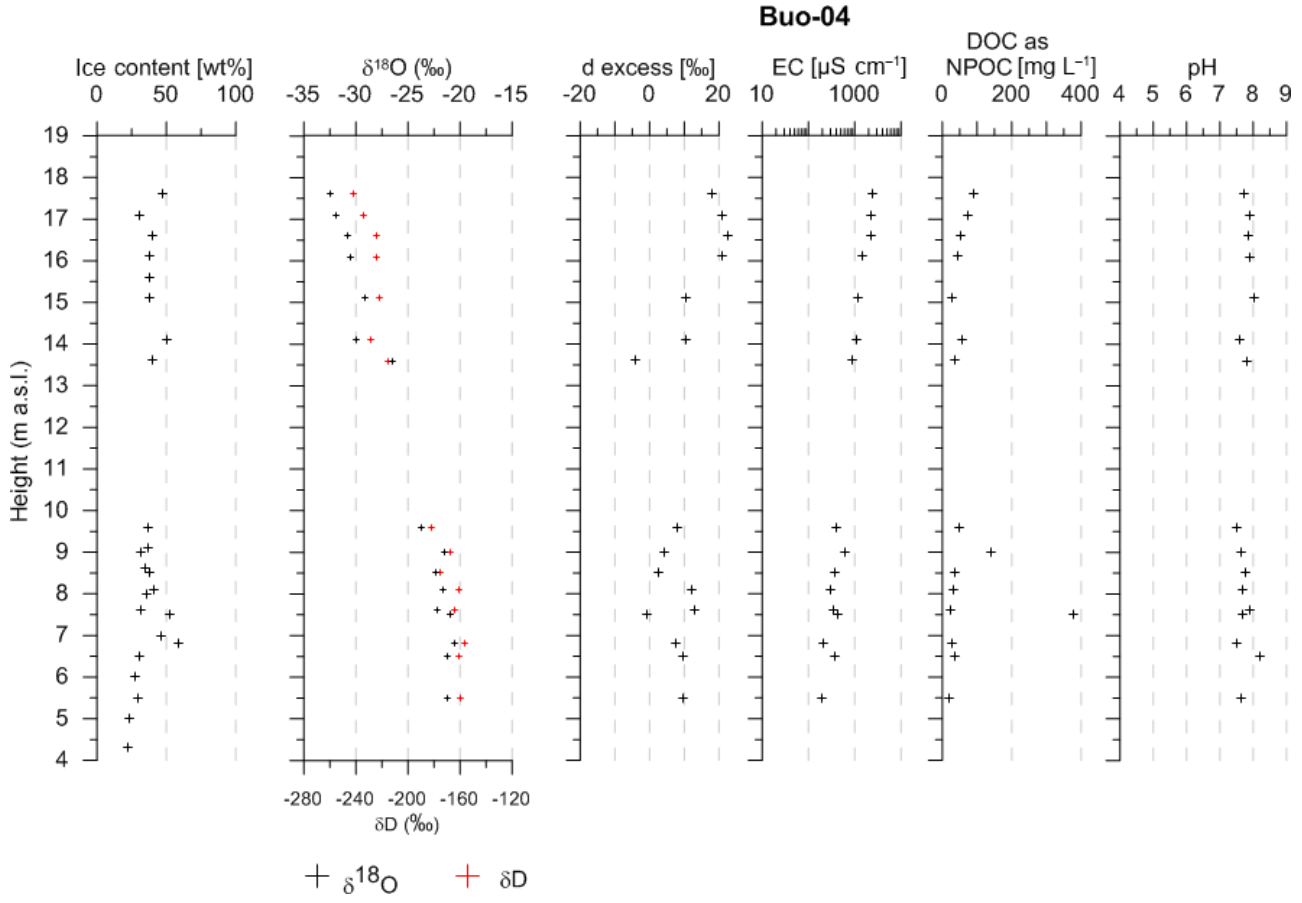

Figure 10. Measurements of ice content, isotope ratios, electrical conductivity (EC), pH, and solutes over height in $\mathrm{m}$ a.s.l. for samples from the Buo-04 exposure.
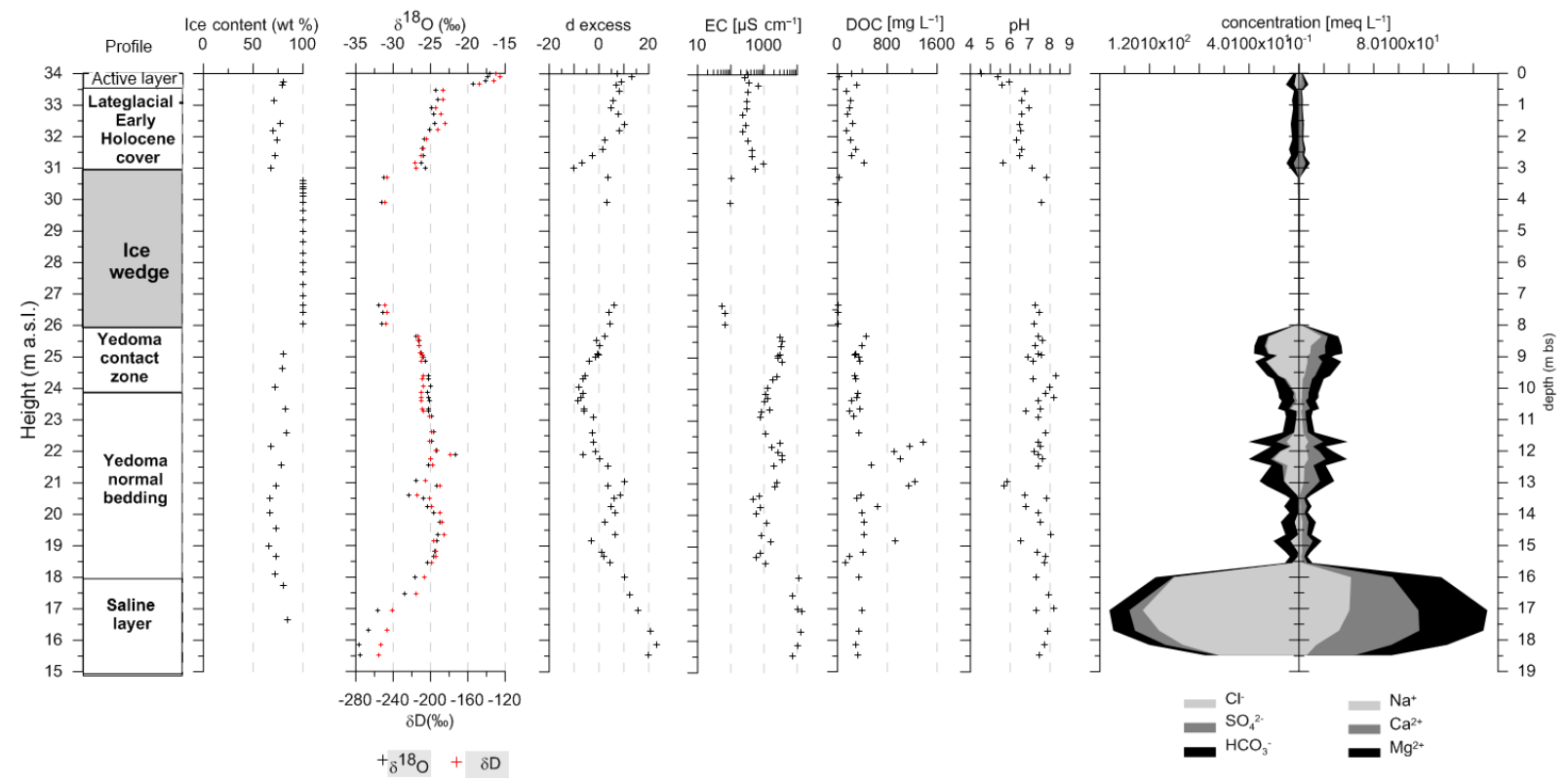

Figure 11. Measurements of ice content, isotope ratios, electrical conductivity (EC), $\mathrm{pH}$, and solutes over depth for samples from the BK-8 core.

Stable isotope ratios are grouped based on source and on their relationship to one another. Samples from BK-8 and the exposures range from -35 to more than $-20 \%$ o $\delta^{18} \mathrm{O}$ (Fig. 12). Within this range, samples grouped above the global meteoric water line (GMWL) at low values, near the GMWL and local meteoric water line (LMWL) for mid- range values, and below the GMWL for mid-range to higher values. This is reflected in the relationship between $d$ excess and $\delta^{18} \mathrm{O}$, for example. The lightest samples in BK8 had positive $d$ excess and came from the 16-18 $\mathrm{m}$ a.s.l. depth range. High $d$-excess values correspond to the lowest $\delta^{18} \mathrm{O}$ values. A decrease in $d$ excess $(-8.6 \%$ ), or the lowest 

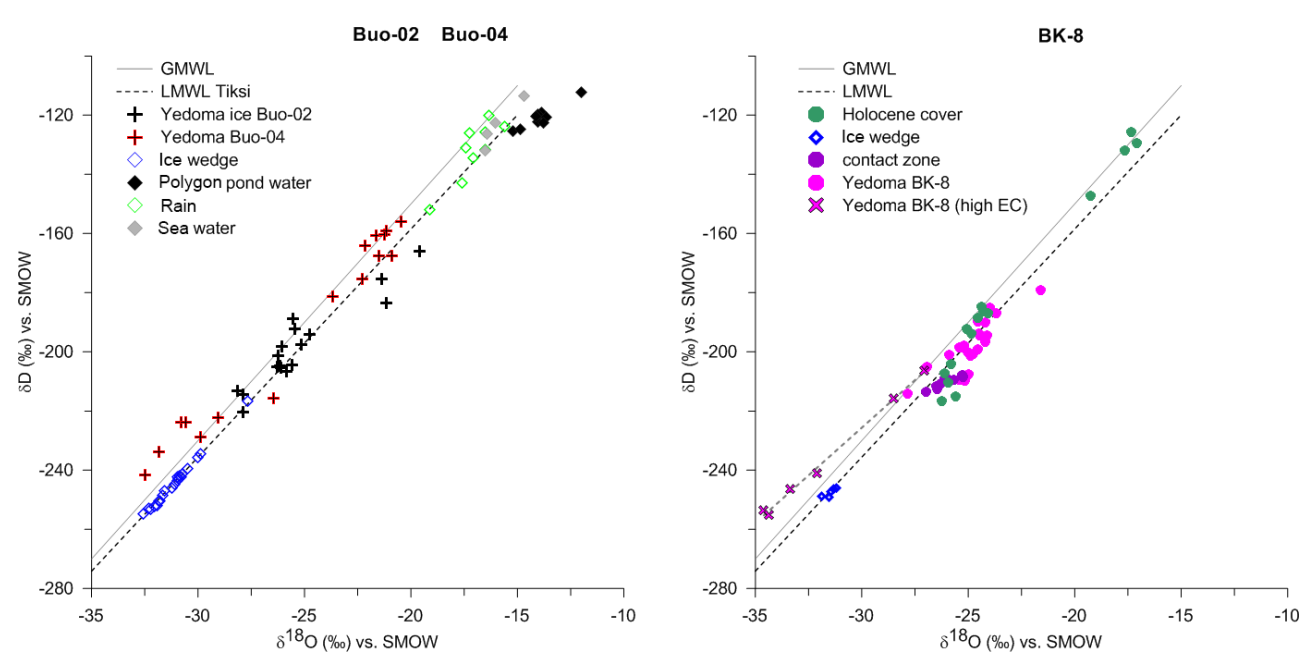

Figure 12. Stable isotope ratios for the Buo- 02 and Buo-04 exposures and the BK- 8 core samples. For reference, they are plotted together with precipitation and meteoric water lines, both global (GMWL; solid line) and local (LMWL; dashed line).

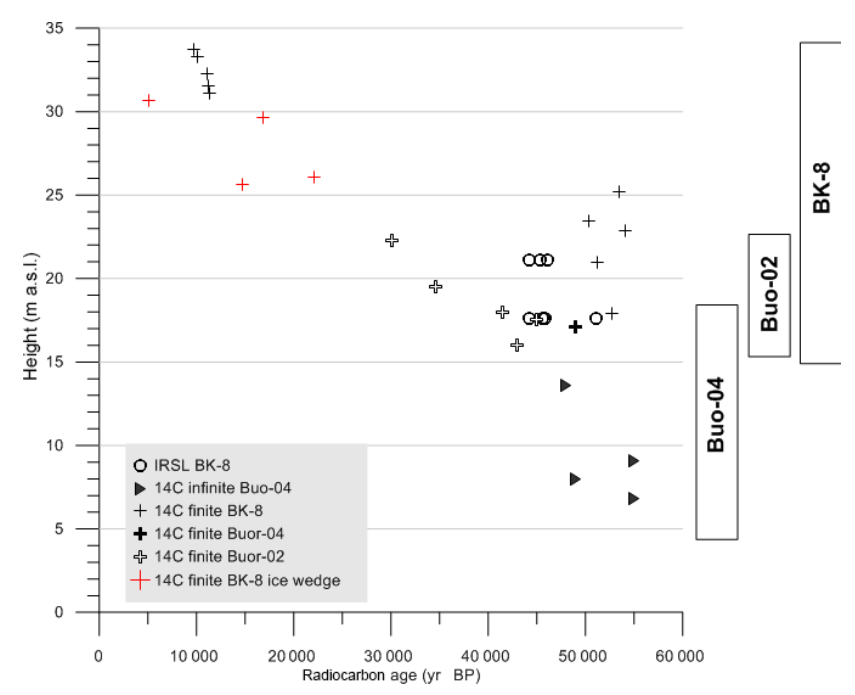

Figure 13. Compilation of geochronological results of Yedoma IC obtained in two profiles (Buo-02, Buo-04) and one drill core (BK-8) at the western coast of Buor Khaya Peninsula.

$d$-excess values $(-14.1 \%$ ) were observed in BK-8 at $23-$ $25 \mathrm{~m}$ a.s.l. and in Buo-02 at $18 \mathrm{~m}$ a.s.l. heights, respectively. Samples recovered from ice wedges, whether in the borehole or not, cluster tightly along the LMWL with lighter values, as expected for this winter precipitation signal. Values from late-glacial-early Holocene cover more closely resemble meteoric waters (rain), both in magnitude and in their ratio to one another.

\section{Discussion}

\subsection{Chronostratigraphy}

The chronostratigraphy of the Buor Khaya Yedoma IC and its overlying late-glacial-early Holocene cover is based on 24 radiocarbon dates and three IRSL datings of the lowermost BK-8 core Yedoma IC unit (Fig. 13). The Buo-04 profile and the BK-8 core deposits below the ice wedge exhibit radiocarbon ages between $54.1 \pm 3.4$ and $49 \pm 3 \mathrm{kyr} \mathrm{BP}$ as well as non-finite ages in Buo-04. The IRSL ages of the lowermost BK-8 core segments range between $51.1 \pm 4.9$ and $44.2 \pm 3.6 \mathrm{kyr}$.

Continued Yedoma IC formation is assumed by sedimentary radiocarbon ages of the Buo-02 profile between $45.0 \pm 2$ and $30.1 \pm 0.3 \mathrm{kyr} \mathrm{BP}$, and ages from the BK-8 ice wedge between $22.1 \pm 0.1$ and $14.7 \pm 0.06 \mathrm{kyr} \mathrm{BP}$. The thermokarst onset during the late-glacial period is a commonly observed feature of late Quaternary permafrost stratigraphies (Kaplina and Lozhkin, 1979; Kaplina, 1981; Romanovskii et al., 2000; Wetterich et al., 2009; Walter Anthony et al., 2014). The radiocarbon ages obtained from OM within the BK- 8 ice wedge, however, confirm that Yedoma IC formation occurred between approx. 30 and $14 \mathrm{kyr} \mathrm{BP}$; these dates are not present in the obtained sedimentary records and ages.

Generally, studying permafrost stratigraphies in palaeoenvironmental research by sampling coastal exposures in sub-profiles and drill cores introduces certain considerations that must be accounted for during data interpretation. The preservation of late Pleistocene ice-rich permafrost depends not only on predominant climate dynamics but also on palaeo-relief conditions and the past spatial distribution of accumulation and erosion areas. To capture the kilometrescale spatial variability, sampling of coastal exposures advances our understanding of this variability, or at least pro- 
vides the chance to relate records of the same age spatially. As shown in Fig. 13 the oldest Yedoma IC units with nonfinite radiocarbon ages were found at different altitudes, below $15 \mathrm{~m}$ a.s.l. for profile Buo-04 and between 16 and $9 \mathrm{~m}$ a.s.l. for core BK-8; this points to different deposition heights within the former surface morphology. The Buo-04 and Buo-02 Buor Khaya Yedoma IC profiles, even though they were sampled at similar altitudes, cover different periods of Yedoma IC deposition; the Buo-04 represents formation $>49 \mathrm{kyr}$ BP, and the Buo-02 represents deposition between approx. 45 and $30 \mathrm{kyr}$ BP. The exposure accessibility and technical difficulties encountered in keeping the sampled material frozen during summer field campaigns as well as the lower sampling resolution, if compared to permafrost drilling in springtime, limit the quality of exposure data. The drilling approach allows for higher sampling resolution of frozen material and better borehole instrumentation for, e.g., groundtemperature measurements. The core material is also limited since it is difficult to choose a drilling location from the ground surface that gives a representative sample and avoids ice wedges. This study attempts to combine the advantages of both stratigraphic sampling methods.

\subsection{Cryostratigraphy and analytical data interpretation}

The Buo-02 and Buo-04 profiles (Figs. 3 to 6) show no distinct internal stratification that allows cryolithological units to be defined within both sequences. However, palaeocryosol horizons at 17 to $18 \mathrm{~m}$ a.s.l. in Buo-02 and at 6 to $8 \mathrm{~m}$ a.s.l. in Buo-04 are remarkable in ice content, BD, TOC, TOC / TN, and $\delta^{13} \mathrm{C}$ values of TOC. These horizons are also noteworthy in heavier stable water-isotope values and lower $d$-excess values (Figs. 9 and 10). However, the hydrochemical data sets do not indicate relevant lithostratigraphical separations. The increasing and decreasing trends of stable waterisotope values and EC values, respectively, will be considered separately.

The BK-8 core is divided into six cryolithological units, according to field observations, core descriptions, and analytical data sets. The active layer ( $34.0-33.45 \mathrm{~m}$ a.s.1.) is characterized by the lightest stable water-isotope values $(-19.3$ to $-17.1 \%$ of $\delta^{18} \mathrm{O},-147.2$ to $-125.7 \%$ for $\delta \mathrm{D}$ ) and the lowest $\mathrm{pH}$ values (5.6 to 4.5). The deposits of the late-glacialearly Holocene cover (33.45-30.85 m a.s.l.) have properties similar to those of the overlying active layer. However, the stable water-isotope signature is clearly different, with a decreasing shift downwards to the underlying ice wedge (Fig. 11). According to pollen data (Zimmermann et al., 2017), the deposits were formed in a shrub-tundra landscape indicating regional climate amelioration during this glacialinterglacial transition period (Andreev et al., 2011). The ice wedge of the BK-8 core (30.8-25.65 ma.s.1.) is clearly distinguishable as a separate unit due to its specific structural characteristics and ground-ice composition. The con- tact zone (25.65-24.05 $\mathrm{m}$ a.s.1.) between IC deposits and the ice wedge is made obvious by diagonally and vertically oriented cryostructures. In addition, there is a clear decrease in TOC, TS, $\delta^{13} \mathrm{C}, \mathrm{EC}$, and $d$-excess values, whereas $\delta \mathrm{D}$ and $\delta^{18} \mathrm{O}$ increase. It should be noted that the contact zone is bent upwards due to processes connected with ice-wedge growth, which is a typical characteristic for syngenetic permafrost (Konishchev, 2002) such as Yedoma IC below the ice wedge; the horizontally bedded Yedoma IC unit is cryostratigraphically distinguished only by the horizontally oriented cryostructures, while sediment and ice characteristics are similar to those in the covering contact zone. Pollen analyses from both segments, the Yedoma contact zone and the regular Yedoma, indicate the presence and partial absence of hydrophytes, respective, reflecting the occurrence of a perennial shallow polygon pond with temporally fluctuating water level (Zimmermann et al., 2016). Finally, the lowermost saline layer (18-15.1 ma.s.l.) was distinguished due to increased $\mathrm{EC}$ values of up to $14 \mathrm{mS} \mathrm{cm}^{-1}$. In addition, the MS values are higher than those in the overlying Yedoma IC deposits.

\subsection{Sediment transport and depositional processes from grain-size end-members}

According to the end-member analysis (Fig. 14) each Yedoma IC sequence is characterized by a specific robust end-member (rEM) signature. However, three typical endmembers (rEM1 to rEM3) with similar patterns are modelled in all three records. The fine-silt rEM1 (main mode at 3$5 \mu \mathrm{m})$ was present in most Buo-02 and Buo-04 samples but did not dominate the sections, while in the BK- 8 permafrost core, it was present mainly in the late-glacial-early Holocene cover and in two samples at 21.5 and $20.5 \mathrm{~m}$ a.s.l. Hence, this rEM might represent an alluvial, unconfined transport of fine material. The medium-silt rEM2 (main mode at 25$30 \mu \mathrm{m}$ ) dominated the upper Buo-04 (down to $13.6 \mathrm{~m}$ a.s.l.) and was rarely found in the lower part of the profile. In BK-8, rEM2 is present in most samples and dominates the lower part. A slight difference appears in Buo-02, where rEM2 is common in three segments separated by dominant coarser end-members. Its broader main mode is shown in Fig. 14a to c, which could point to a secondary transport mechanism involved. For example, after aeolian deposition on the slopes the sediment was relocated towards the site in unconfined alluvial flow (similar to what is described in Dietze et al., 2012). The very fine-sand rEM3 (main mode at $60-80 \mu \mathrm{m}$ ) dominated the sand layers in Buo-02 at 15.5, 17, and $18.5 \mathrm{~m}$ a.s.1. The rEM3 also characterizes the sand layers in Buo-04 at 16, 22, 24-25, 31, and $33.5 \mathrm{~m}$ a.s.l., and even dominates the entire lower part of this profile (Fig. 14d to f), but appears only sporadically in the BK-8 core sequence. We assume a short-term localized aeolian transport during peak wind intensities to have created these layers (Tsoar and Pye, 1987; Dietze et al., 2014). In Buo-02, two additional 
(a)

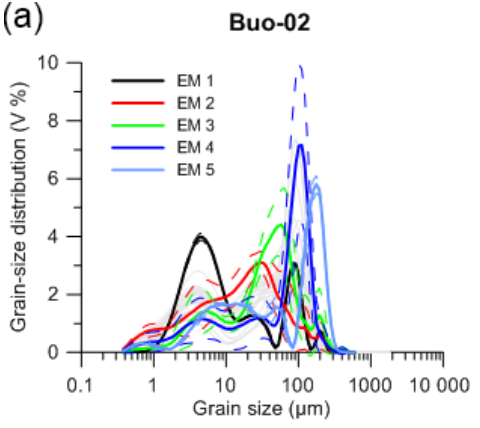

(d)
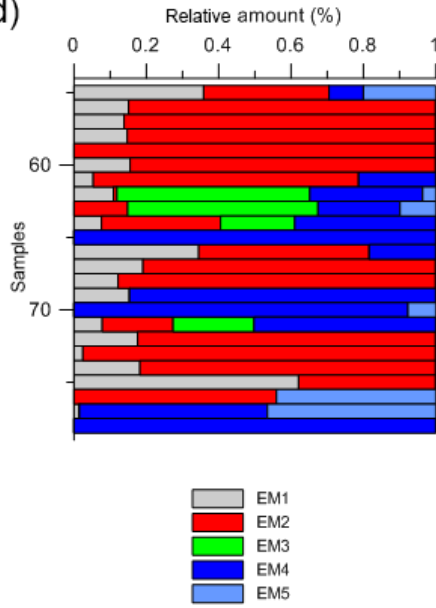

(b)

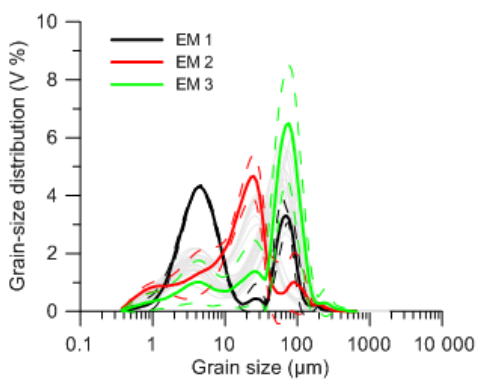

(e)

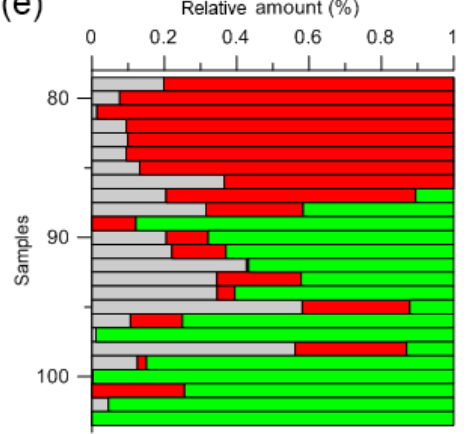

(c) BK-8

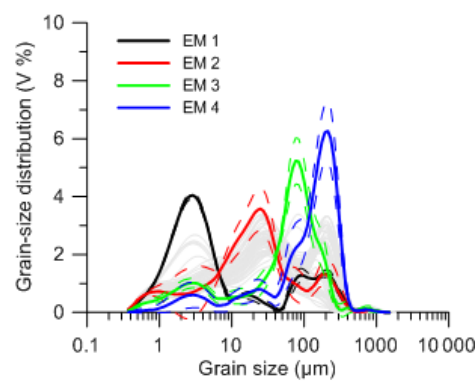

(f)

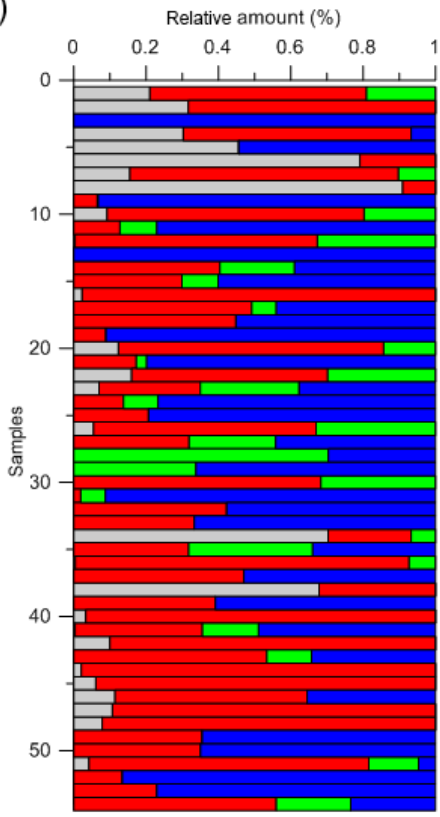

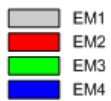

Figure 14. Results of the end-member analysis of the studied Buo-02, Buo-04, and BK-8 sequences; $(\mathbf{a}, \mathbf{b}, \mathbf{c})$ results of robust end-member modelling (grey curves in the background represent the original grain-size distributions of each sample; dashed lines mark the standard deviation for each end-member); (d, e, f) distribution of robust end-member loadings for each sample (note: due to better visibility loadings are not plotted with depth but in the same order).

end-members (rEM4, rEM5) were separated in the fine-sand fraction with the main modes at 111 and $177 \mu \mathrm{m}$, respectively, while in BK-8 rEM4 was calculated in the mediumsand fraction with a main mode at $213 \mu \mathrm{m}$. These three specific sandy rEMs might be related to short-term fluvial (confined) transport processes, as they are too coarse for aeolian transport (Tsoar and Pye, 1987). The various grain-size end-members support the hypothesis of polygenetic Yedoma IC origin involving multiple transport and depositional processes, which might be overprinted by in situ frost weathering.

\subsection{Polygenetic origin of Yedoma soils}

The Yedoma IC formation comprises primary soil accumulation and cryogenic processes, for instance cryogenic weathering, ice segregation, syngenetic ice-wedge growth, secondary sediment deformation, and reworking due to cryoturbation. Such processes were supported by the long-lasting severe continental climate conditions of the late Pleistocene. Moreover, the formation of large polygon ice-wedge nets and thick continuous ice-rich permafrost deposits was related to the existence of stable, poorly drained accumulation plains with low inclination. In contrast to the loess hypotheses of Yedoma IC formation (e.g. Tomirdiaro, 1980; Murton et al., 2015), the proposed cryolithogenetic concept integrates several previous formation concepts and, in particular, takes into 


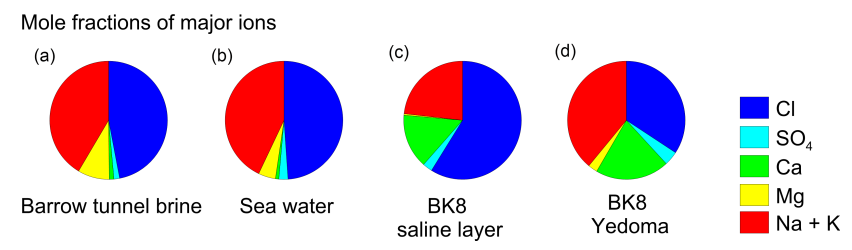

Figure 15. Comparison of major ion composition of (a) saline brine from the Barrow permafrost tunnel in Alaska (Colangelo-Lillis et al., 2016), (b) sea water with the pore water in the BK-8 Yedoma core from the lowermost saline layers (c), and the overlying Yedoma (d).

account the important role of ground ice in the deposit formation process. Generally, this corresponds to the polygenetic character of Yedoma IC formation. It also includes the potential for several sediment sources, weathering processes, and pathways by which sediments in typical periglacial landscapes can build up the Yedoma IC.

Whereas the EC of pore solutions in Buo-02, Buo-04, and most of BK-8 is less than $3000 \mu \mathrm{S} \mathrm{cm}^{-1}$ throughout, pore solutions below $19 \mathrm{~m}$ a.s.l. exceed $10 \mathrm{mS} \mathrm{cm}^{-1}$, which is not typical for Yedoma IC sediments, and require explanation. The pore-water geochemistry of permafrost may reflect differences in mineral source material and the mechanical and biochemical weathering of that material, but may also be affected by processes active during deposition or processes that occurred following deposition and freezing. Concentration of solutes can result from phase change (evaporation or sublimation of surface waters, exclusion and migration of solutes from freezing pore solution; Jouzel and Souchez, 1982) and can lead to secondary effects such as the precipitation of mineral phases from solution.

We suggest that the saline layer at the bottom of BK-8 is the result of Rayleigh fractionation during the re-freezing of a thawed layer from above. There are numerous points to support this interpretation. First, neither the age nor the composition of the BK-8 mineral component show changes correlated with the more concentrated solution, with the possible exception of somewhat higher MS. Second, the concomitant increase in $d$ excess and decrease in $\delta^{18} \mathrm{O}$ and $\delta \mathrm{D}$ for pore water below $16 \mathrm{~m}$ b.s.l (below $18 \mathrm{~m}$ a.s.l.) suggests Rayleigh fractionation during phase change. The negative correlation between $\delta \mathrm{D}$ and $d$ excess (with a slope of -0.2) reflects freezing processes rather than meteoric precipitation as a source (Souchez et al., 2000; Lacelle, 2011). Based on the distribution of both over depth, freezing occurred from above in the segment from at least $16 \mathrm{~m}$ down to the bottom of the core at $18.4 \mathrm{~m}$ depth. Isotope ratios are consistent with Rayleigh fractionation from source water with the isotope ratio in the Yedoma IC above this lowest segment, using the equilibrium coefficients for the fractionation of $\delta^{18} \mathrm{O}$ and $\delta \mathrm{D}$ during freezing from Suzuoki and Kimura (1973); therefore, an exogenous water source is not necessary to explain the change in isotope ratios over depth. Third, the in- creased EC below this depth is consistent with solute concentration due to the removal of solvent by freezing from the pore solution. The pore-water composition does not support an exogenous source for the hydrochemistry; means of major dissolved species concentrations $\left(\mathrm{Na}^{+}, \mathrm{K}^{+}, \mathrm{Mg}^{2+}, \mathrm{Ca}^{2+}\right.$, $\mathrm{Cl}^{-}$) in sea water, marine brines, normally bedded BK-8 Yedoma, and BK-8 saline layer with higher EC also suggest a non-marine origin for the higher concentration of solutes (Fig. 15). Taken together, the isotope concentrations and EC indicate that unidirectional freezing from above of the lower $2.5 \mathrm{~m}$ of BK-8 took place in a medium that was necessarily unfrozen. The presence of high but variable concentrations of solutes in the pore water throughout this layer is generally consistent with concentration effects in slowly freezing soils (Chuvilin, 1999), but the source of the solutes is not clear, since their concentration exceeds what would be available in the Yedoma IC sequence.

We therefore suggest that during the warm and moist summer conditions of the MIS 3 interstadial period (Andreev et al., 2011; Wetterich et al., 2014), a talik horizon more than $2.5 \mathrm{~m}$ thick developed and subsequently re-froze making it post-depositional epigenetic permafrost. Such thawing and re-freezing can be observed, for example, in thaw bulbs beneath small water bodies such as polygon ponds (Langer et al., 2011). Our borehole was not deep enough to capture the lower boundary of this post-deposition re-freezing process nor to determine how local this phenomenon is.

According to pollen data from Zimmermann et al. (2016), the saline layer segment of the BK-8 core is characterized by increasing wetness (e.g. algae and spores) but also increasing shrub and tree taxa (Pinus, Picea, Betula, and Al$n u s)$, which presumably originated from redeposited preQuaternary pollen.

Our comprehensive cryolithogenetic concept of polygenetic Yedoma formation (Schirrmeister et al., 2013) combines cryogenic weathering, periglacial material transport and accumulation, and relief shaping under cold-arid climate conditions and considers two general formation processes: (1) primary accumulation in low-centred ice-wedge polygons and (2) syngenetic freezing and ice-wedge growth. Following this concept, the Yedoma IC represents a specific periglacial facies, whose formation is controlled by the interaction of climate, landscape, and geological preconditions typical for non-glaciated Arctic and subarctic lowlands and foothills.

\subsection{Regional context of Yedoma Ice Complex in eastern Siberia}

Comparing the records of the Buor Khaya Yedoma IC with the well-studied profiles of the Bykovsky Peninsula (Fig. 1; e.g. Schirrmeister et al., 2002; Sher et al., 2005; Grosse et al., 2007) approx. $100 \mathrm{~km}$ west, the study sites of Mus Khaya on the Yana River approx. $150 \mathrm{~km}$ south-east (Konishchev, 2013) as well as the coastal exposure from Bol'shoy Lyakhovsky Island (Fig. 1; Andreev et al., 2009; Wetterich 

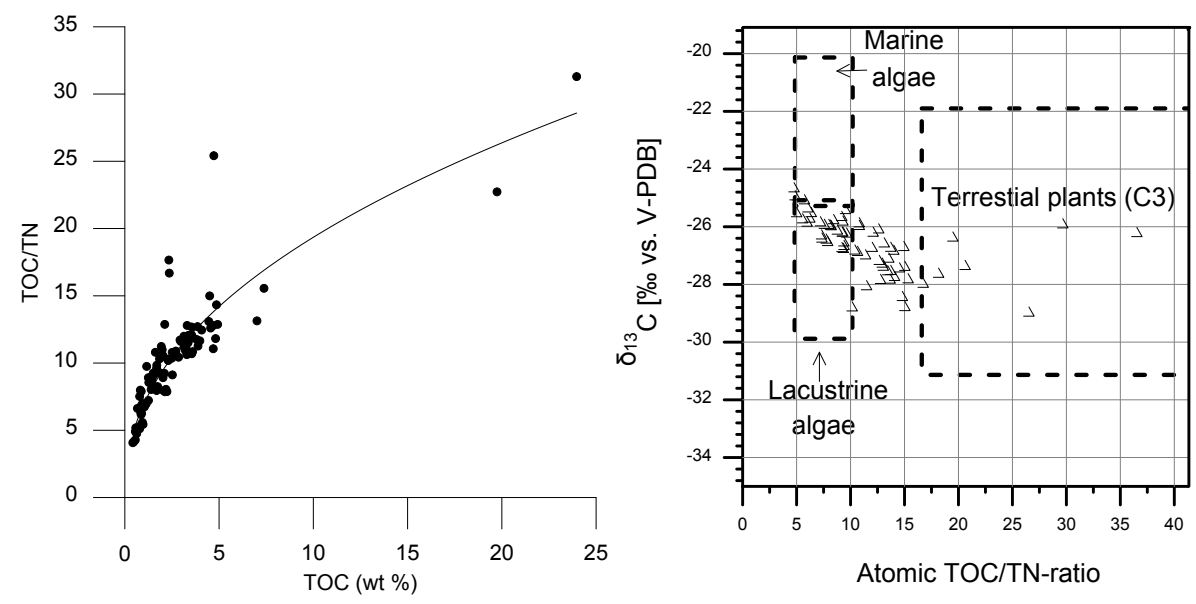

Figure 16. Organic matter characteristics of the Buor Khaya Yedoma. Left: correlation of the TOC content and the TOC / TN ratio. Right: distribution of the TOC $-\delta^{13} \mathrm{C}_{\mathrm{TOC}}$ relationships according to Meyers (1997).

et al., 2011a, b, 2014) approx. $350 \mathrm{~km}$ north-east of Buor Khaya Peninsula, we come to the conclusion that these sections formed during the same period between approx. 60 and $12 \mathrm{kyr}$ BP (late MIS 4 to MIS 2), which is typical for Yedoma IC formation (Schirrmeister et al., 2011b). The cryostructures observed at the studied Yedoma IC sequences as well as the major cryolithological parameters are also similar in range and internal variations. In this sense the Buor Khaya Yedoma IC generally belongs to the same late Pleistocene palaeo-environment and was formed under similar palaeo-climatological and palaeo-geographical conditions as Yedoma IC remains around the Laptev Sea.

The ground-temperature record (Fig. 2) does not show any specific variations due to palaeo-warming signals or heat transfer from the Laptev Sea. However, the typical warming of cold permafrost around the Arctic (Romanovsky et al., 2010) and in Siberian Yedoma boreholes at Cape Mamontov Klyk in the western Laptev Sea (Overduin et al., 2008) or at the Mamontovy Khayata site on the Bykovsky Peninsula (Kholodov, 2009) was not observed here.

Summarizing the OM characteristics, the Yedoma IC deposits from the Buor Khaya Peninsula contain $2.04+$ $1.27 /-1.05 \mathrm{wt} \%$ TOC (median with interquartile ranges). The TOC / TN ratio (to estimate the degree of OM decomposition) ranges between strongly decomposed (4.1) and not decomposed (31.3) states. High-OM contents are less decomposed and low-OM contents are strongly decomposed $\left(\ln (Y)=0.446 \times \ln (X)+1.94, R^{2}=0.82, n=97\right.$, Fig. 16). The $\delta^{13} \mathrm{C}$ OM values vary between -29.0 and $-24.7 \%$. According to Meyers (1997), the relationship between atomic TOC / TN ratios and $\delta^{13} \mathrm{C}$ of TOC reflects the existence of C3 land plants as well as lacustrine algae. Comparing the analysed DOC pore-water concentration of approx. 10 to $1370 \mathrm{mg} \mathrm{L}^{-1}$ with the free acetate fraction within the pore water studied by Stapel et al. (2016) of up to $500 \mathrm{mg} \mathrm{L}^{-1}$ it can be concluded that the DOC is composed of substantial proportions of free acetate.

When considering that the Yedoma IC exposed at the Laptev Sea coasts provides source material for marine deposits and is a terrigenic end-member of organic carbon on the eastern Siberian shelf, the study of the composition and formation of Yedoma IC is essential to understanding the fate of terrigenous OM across the Laptev Sea as studied by Bröder et al. (2016), whose marine transect began in the Buor Khaya Bay. The $\delta^{13} \mathrm{C}$ signatures for marine surface sediments are -26.6 to $-25.6 \%$ from the Buor Khaya Bay (Bischoff et al., 2016) and -26.5 to $-22.2 \%$ or a transect across the Laptev Sea (Bröder et al., 2016). The range of $\mathrm{TN}$ values $(0.03$ to $0.45 \mathrm{wt} \%)$ and atomic TOC / TN ratios (21.7 to 68) of Buor Khaya Bay surface sediments presented by Winterfeld et al. (2015) span ranges similar to those of the Buor Khaya Yedoma IC deposits (TN: 0.1 to $0.47 \mathrm{wt} \%$; atomic TOC / TN ratio: 4.8 to 36.5 ). These OM parameters reflect the fact that important parts of terrestrial OM still remain in marine surface deposits and support studies of source, transport, and fate of OM on the East Siberian Arctic Shelf, starting with the terrigenic end-member, i.e. eroding permafrost coasts.

\section{Conclusions}

The studied Yedoma IC permafrost exposed at the western coast of the Buor Khaya Peninsula in the central Laptev Sea accumulated from approx. 54.1 $\pm 3.4 \mathrm{kyr}$ BP (IRSL age $51.1 \pm 4.9 \mathrm{kyr}$ ) until the onset of the late-glacial-Holocene warming. The timing of IC formation and its cryolithological properties are similar to known Yedoma IC sequences in the Laptev Sea region. Three to five robust end-members (rEMs) represent fine-silt, medium-silt, and fine-sand fractions in grain-size distribution data, which support the con- 
cept of multiple transport and depositional processes during IC formation. Post-depositional re-freezing processes during the MIS3 interstadial with relatively warm and moist summer conditions created unusually high-solute concentrations in pore water. The OM characteristics of the Yedoma IC reflect typical continental tundra-steppe environments of western Beringia during the late Pleistocene. Eroding Yedoma IC deposits are one of the OM sources in the marine realm of the Laptev Shelf.

Data availability. The data in this article are available at doi:10.1594/PANGAEA.847262 (Overduin, 2015).

\section{The Supplement related to this article is available online at doi:10.5194/bg-14-1261-2017-supplement.}

Competing interests. The authors declare that they have no conflict of interest.

Acknowledgements. The study presented here is part of the Helmholtz-Russia Joint Research Group. We gratefully acknowledge the German Federal Ministry of Education and Research (BMBF) for funding this study as part of the joint German-Russian research project CARBOPERM (03G0836B, 03G0836F). Moreover, we acknowledge the support by the European Research Council (starting grant no. 338335) and the Initiative and Networking Fund of the Helmholtz Association (no. ERC-0013). We thank our colleagues, who helped during fieldwork in 2014, especially Dmitry Mel'nichenko and colleagues from the Hydrobase Tiksi, and Waldemar Schneider from AWI Potsdam, who greatly supported the logistics of this expedition. The analytical work in the AWI laboratories was expertly conducted by Ute Bastian, Dyke Scheidemann, Antje Eulenburg, Hanno Meyer, and Lutz Schönicke. We are grateful to Marcus Richter (TU Dresden) and to Ingrid Stein (TU Bergakademie Freiberg) for IRSL analyses, and to Jörg Erzinger, Sabine Schumann (GFZ Potsdam), and Torben Windirsch (University of Potsdam) for TS measurements. Finally, the paper benefited from the reviews of Mikhail Kanevskiy (University of Alaska Fairbanks) and one anonymous reviewer with constructive comments, and English language corrections from Candace O'Connor (Fairbanks Alaska).

The article processing charges for this open-access publication were covered by a Research Centre of the Helmholtz Association.

Edited by: A. V. Eliseev

Reviewed by: M. Kanevskiy and one anonymous referee

\section{References}

Aitken, M. J.: An Introduction to Optical Dating. The Dating of Quaternary Sediments by the Use of Photon-Stimulated Luminescence, xi +267 pp., Oxford, New York, Tokyo: Oxford University Press, 1998.

Andreev, A., Grosse, G., Schirrmeister, L., Kuznetsova, T. V., Kuzmina, S. A., Bobrov, A. A., Tarasov, P. E., Novenko, E. Yu., Meyer, H., Derevyagin, A. Yu., Kienast, F., Bryantseva, A., and Kunitsky, V. V.: Weichselian and Holocene palaeoenvironmental history of the Bol'shoy Lyakhovsky Island, New Siberian Archipelago, Arctic Siberia, Boreas, 38, 72-110, doi:10.1111/j.1502-3885.2008.00039.x, 2009.

Andreev, A., Schirrmeister, L., Tarasov, P. E., Ganopolski, A., Brovkin, V., Siegert, C., Wetterich, S., and Hubberten, H.-W.: Vegetation and climate history in the Laptev Sea region (Arctic Siberia) during Late Quaternary inferred from poll records, Quaternary Sci. Rev., 30, 2182-2199, doi:10.1016/j.quascirev.2010.12.026, 2011.

Bischoff, J., Sparkes, R. B., Dogrul Selver, A., Spencer, R. G. M., Gustafsson, Ö., Semiletov, I. P., Dudarev, O. V., Wagner, D., Rivkina, E., van Dongen, B. E., and Talbot, H. M.: Source, transport and fate of soil organic matter inferred from microbial biomarker lipids on the East Siberian Arctic Shelf, Biogeosciences, 13, 4899-4914, doi:10.5194/bg-13-4899-2016, 2016.

Bobrov, A. A., Andreev, A. A., Schirrmeister, L., and Siegert, C.: Testate amoebae (Protozoa: Testacealobosea and Testaceafilosea) as bioindicators in the Late Quaternary deposits of the Bykovsky Peninsula, Laptev Sea, Russia, Palaeogeogr. Palaeocl., 209, 165-181, doi:10.1016/j.palaeo.2004.02.012, 2004.

Bøtter-Jensen, L., Andersen, C. E., Duller, G. A. T., and Murray, A. S.: Developments in radiation, stimulation and observation facilities in luminescence measurements, Radiat. Meas., 37, 535541, 2003.

Bray, M. T., French, H. M., and Shur, Y.: Further cryostratigraphic observations in the CRREL Permafrost Tunnel, Fox, Alaska, Permafrost Periglac., 17, 233-243, doi:10.1002/ppp.558, 2006.

Bröder, L., Tesi, T., Salvadó, J. A., Semiletov, I. P., Dudarev, O. V., and Gustafsson, Ö.: Fate of terrigenous organic matter across the Laptev Sea from the mouth of the Lena River to the deep sea of the Arctic interior, Biogeosciences, 13, 5003-5019, doi:10.5194/bg-13-5003-2016, 2016.

CAVM Team: Circumpolar Arctic vegetation map (1:7,500,000 scale). Conservation of Arctic flora and fauna (CAFF), Map No. 1, U.S. Fish and Wildlife Service, Anchorage, Alaska, available at: http://www.geobotany.uaf.edu/cavm/ (last access: 18 January 2016), 2003.

Chuvilin, E. M.: Migration of ions of chemical elements in freezing and frozen soils, Polar record, 35, 59-66, 1999.

Colangelo-Lillis, J., Eicken, H., Carpenter, S. D., and Deming, J. W.: Evidence for marine origin and microbial-viral habitability of sub-zero hypersaline aqueous inclusions within permafrost near Barrow, Alaska, FEMS Microbiol. Ecol., 92, fiw053, doi:10.1093/femsec/fiw053, 2016.

Dansgaard, W.: Stable isotopes in precipitation, Tellus, 16, 436468, 1964.

Dietze, E., Hartmann, K., Diekmann, B., Ilmker, J., Lehmkuhl, F., Opitz, S., Stauch, G., Wünnemann, B., and Borchers, A.: An end-member algorithm for deciphering modern detrital pro- 
cesses from lake sediments of Lake Donggi Cona, NE Tibetan Plateau, China, Sediment. Geol., 243-244, 149-180, doi:10.1016/j.sedgeo.2011.09.014, 2012.

Dietze, E., Maussion, F., Ahlborn, M., Diekmann, B., Hartmann, K., Henkel, K., Kasper, T., Lockot, G., Opitz, S., and Haberzettl, T.: Sediment transport processes across the Tibetan Plateau inferred from robust grain-size end members in lake sediments, Clim. Past, 10, 91-106, doi:10.5194/cp-10-91-2014, 2014.

Drozdov, D. S., Rivkin, F. M., Rachold, V., Ananjeva-Malkova, G. V., Ivanova, N. V., Chehina, I. V., Koreisha, M. M., Korostelev, Y. V., and Melnikov, E. S.: Electronic atlas of the Russian Arctic coastal zone, Geo-Mar. Lett., 25, 81-88, doi:10.1007/s00367004-0189-7, 2005.

Duller, G. A. T.: Analyst v4.31.9 user manual. Aberystwyth Luminescence Research Laboratory, Aberystwyth University, 83 pp., available at: http://users.aber.ac.uk/ggd/, 2016.

French, H. and Shur, Y.: The principles of cryostratigraphy, EarthSci. Rev., 101, 190-206, doi:10.1016/j.earscirev.2010.04.002, 2010.

Froese, D. G., Westgate, J. A., Preece, S. J., Sandborn, P. T., Reyes, A. V., and Pearce, N. J. G.: The Klondike goldfields and Pleistocene environments of Beringia, GSA Today, 19, 4-10, doi:10.1130/GSATG54A.1, 2009.

Galbraith, R. F., Roberts, R. G., Laslett, G. M., Yoshida, H., and Olley, J. M.: Optical dating of single and multiple grains of quartz from Jinmium Rock Shelter, Northern Australia: part I, experimental design and statistical model, Archaeometry, 41, 339-364, doi:10.1111/j.1475-4754.1999.tb00987.x, 1999.

Grosse, G., Schirrmeister, L., Siegert, Ch., Kunitsky, V. V., Slagoda, E. A., Andreev, A. A., and Dereviagyn, A. Y.: Geological and geomorphological evolution of a sedimentary periglacial landscape in Northeast Siberia during the Late Quaternary, Geomorphology, 86, 25-51, doi:10.1016/j.geomorph.2006.08.005, 2007.

Gubin, S. V. and Zanina, O. G.: Variation of soil cover during the Ice Complex deposit formation, Kolyma Lowland (Part 1), Earth Cryosphere, XVII, 48-56, 2013 (in Russian).

Gubin, S. V. and Zanina, O. G.: Variation of soil cover during the Ice Complex deposit formation, Kolyma Lowland (Part 2), Earth Cryosphere, XVIII, 77-82, 2014 (in Russian).

Günther, F., Overduin, P. P., Makarov, A. S., and Grigoriev, M. N. (Eds.): Russian-German Cooperation SYSTEM LAPTEV SEA: The Expeditions Laptev Sea - Mamontov Klyk 2011 \& Buor Khaya 2012, Berichte zur Polar- und Meeresforschung (Reports on Polar and Marine Research), 664, 113 pp., doi:10.2312/BzPM_0664_2013, 2013a.

Günther, F., Overduin, P. P., Sandakov, A. V., Grosse, G., and Grigoriev, M. N.: Short- and long-term thermo-erosion of ice-rich permafrost coasts in the Laptev Sea region, Biogeosciences, 10, 4297-4318, doi:10.5194/bg-10-4297-2013, 2013 b.

Hamilton, T. D., Craig, J. L., and Sellmann, P. V.: The Fox permafrost tunnel: a late Quaternary geologic record in central Alaska, Geol. Soc. Am. Bull., 100, 948-969, doi:10.1130/00167606(1988)100<0948:TFPTAL>2.3.CO;2, 1988.

Hoefs, J.: Stable Isotope Geochemistry, Springer-Verlag, Berlin, Heidelberg, 201 pp., 1997.

Hugelius, G., Strauss, J., Zubrzycki, S., Harden, J. W., Schuur, E. A. G., Ping, C.-L., Schirrmeister, L., Grosse, G., Michaelson, G. J., Koven, C. D., O’Donnell, J. A., Elberling, B., Mishra, U., Camill, P., Yu, Z., Palmtag, J., and Kuhry, P.: Estimated stocks of circumpolar permafrost carbon with quantified uncertainty ranges and identified data gaps, Biogeosciences, 11, 6573-6593, doi:10.5194/bg-11-6573-2014, 2014.

Jakobsson, M., Mayer, L. A., Coakley, B., Dowdeswell, J. A., Forbes, S., Fridman, B., Hodnesdal, H., Noormets, R., Pedersen, R., Rebesco, M., Schenke, H.-W., Zarayskaya A, Y., Accettella, D., Armstrong, A., Anderson, R. M., Bienhoff, P., Camerlenghi, A., Church, I., Edwards, M., Gardner, J. V., Hall, J. K., Hell, B., Hestvik, O. B., Kristoffersen, Y., Marcussen, C., Mohammad, R., Mosher, D., Nghiem, S. V., Pedrosa, M. T., Travaglini, P. G., and Weatherall, P.: The International Bathymetric Chart of the Arctic Ocean (IBCAO) Version 3.0, Geophys. Res. Lett., 39, L12609, doi:10.1029/2012GL052219, 2012.

Jouzel, J. and Souchez, R. A.: Melting-refreezing at the glacier sole and the isotopic composition of the ice, J. Glaciol., 28, 35-42, 1982.

Kanevskiy, M. Z., French, H. M., and Shur, Y. L. (Eds.): LatePleistocene syngenetic permafrost in the CRREL permafrost tunnel, Fox, Alaska, A Guidebook, Ninth International Conference on Permafrost, Institute of Northern Engineering, University of Alaska Fairbanks, 29 June-3 July 2008, 1-22, 2008.

Kanevskiy, M., Shur, Y., Fortier, D., Jorgenson, M. T., and Stephani, E.: Cryostratigraphy of late Pleistocene syngenetic permafrost (yedoma) in northern Alaska, Itkillik River exposure, Quaternary Res., 75, 584-596, doi:10.1016/j.yqres.2010.12.003, 2011.

Kaplina, T. N.: The History of frozen layers of Northern Yakutia during the late Cenozoic. History and Development - permafrost deposits in Eurasia, Izdatel'vo “Nauka” Moscow, 152-181, 1981 (in Russian).

Kaplina, T. N. and Lozhkin, A. V.: The age of alas deposits in coastal lowland of Yakutia. Izvestiya Akademik Nauk SSSR, Seriya Geologicheskaya, 2, 69-76, 1979 (in Russian).

Katasonov, E. M.: Frozen-ground and facies analysis of Pleistocene deposits and paleogeography of Central Yakutia, Biuletyn Peryglacjalny, 24, 33-40, 1975.

Kholodov, A.: Network of permafrost observatories in North America and Russian deep boreholes, NSF Arctic Data Center, doi:10.18739/A25S8P, 2009.

Kienast, F., Schirrmeister, L., Siegert, C., and Tarasov, P.: Palaeobotanical evidence for warm summers in the East Siberian Arctic during the last cold stage, Quaternary Res., 63, 283-300, doi:10.1016/j.yqres.2005.01.003, 2005.

Knoblauch, C., Beer, C., Sosnin, A., Wagner, D., and Pfeiffer, E.M.: Predicting long-term carbon mineralization and trace gas production from thawing permafrost of Northeast Siberia, Glob. Change Biol., 19, 1160-1172, doi:10.1111/gcb.12116, 2013.

Konishchev, V. N.: Paleotemperature conditions of formation and deformation of Ice Complex Layers, Earth's Cryosphere, 6, 1724, 2002 (in Russian).

Konishchev, V. N.: Nature of the cyclic structure of Ice Complex, East Siberia, Earth's Cryosphere, 17, 3-16, 2013 (in Russian).

Krbetschek, M. R., Götze, J., Dietrich, A., and Trautmann, T.: Spectral information from minerals relevant for luminescence dating, in: Review on luminescence and electron spin resonance dating and allied research, edited by: Wintle, A. G., Radiat. Meas., 27, 695-748, doi:10.1016/S1350-4487(97)00223-0, 1997.

Kreutzer, S., Schmidt, C., Fuchs, M. C., Dietze, M., Fischer, M., and Fuchs, M.: Introducing an R package for luminescence dating analysis, Ancient TL, 30, 1-8, 2012. 
Lacelle, D.: On the $\delta^{18} \mathrm{O}, \delta \mathrm{D}$ and D-excess relations in meteoric precipitation and during equilibrium freezing: Theoretical approach and field examples, Permafrost Periglac., 22, 13-25, doi:10.1002/ppp.712, 2011.

Langer, M., Westermann, S., Muster, S., Piel, K., and Boike, J.: The surface energy balance of a polygonal tundra site in northern Siberia - Part 2: Winter, The Cryosphere, 5, 509-524, doi:10.5194/tc-5-509-2011, 2011.

Meyer, H., Schönicke, L., Wand, U., Hubberten, H.-W., and Friedrichsen, H.: Isotope studies of hydrogen and oxygen in ground ice - experiences with the equilibration technique, Isot. Environ. Health S., 36, 133-149, doi:10.1080/10256010008032939, 2000.

Meyer, H., Dereviagin, A. Yu., Siegert, C., and Hubberten, H.-W.: Paleoclimate studies on Bykovsky Peninsula, North Siberia - hydrogen and oxygen isotopes in ground ice, Polarforschung, 70, 37-51, 2002a.

Meyer, H., Dereviagin, A. Yu., Siegert, C., Schirrmeister, L., and Hubberten, H.-W.: Paleoclimate reconstruction on Big Lyakhovsky Island, North Siberia - hydrogen and oxygen isotopes in ice wedges, Permafrost Periglac., 13, 91-105, doi:10.1002/ppp.416, 2002b.

Meyers, P. A.: Organic geochemical proxies of paleoceanographic, paleolimnologic, and paleoclimatic processes, Org. Geochem., 27, 213-250, 1997.

Morgenstern, A., Grosse, G., Arcos, D. R., Günther, F., Overduin, P. P., and Schirrmeister, L.: The role of thermal erosion in the degradation of Siberian ice-rich permafrost, J. Geophys. Res.Earth Surface, in review, 2017.

Müller, S., Bobrov, A. A., Schirrmeister, L., Andreev, A. A., and Tarasov, P. E.: Testate amoebae record from the Laptev Sea coast and its implication for the reconstruction of Late Pleistocene and Holocene environments in the Arctic Siberia, Palaeogeogr. Palaeocl., 271, 301-315, doi:10.1016/j.palaeo.2008.11.003, 2009.

Murray, A. S. and Wintle, A. G.: Luminescence dating of quartz using an improved single-aliquot regenerative-dose protocol, Radiat. Meas., 32, 57-73, 2000.

Murray, A. S. and Wintle, A. G.: The single aliquot regeneration dose protocol: potential for improvements in reliability, Radiat. Meas., 32, 377-381, 2003.

Murton, J. B., Goslar, T., Edwards, M. E., Bateman, M. D., Danilov, P. P., Savvinov, G. N., Gubin, S. V., Ghaleb, B., Haile, J., Kanevskiy, M., Lozhkin, A. V., Lupachev, A. V., Murton, D. K., Shur, Y., Tikhonov, A., Vasil'chuk, A. C., Vasil'chuk, Y. K., and Wolfe, S. A.: Palaeoenvironmental interpretation of Yedoma silt (Ice Complex) deposition as cold-climate loess, Duvanny Yar, Northeast Siberia, Permafrost Periglac., 26, 208-288, doi:10.1002/ppp.1843, 2015.

Overduin, P. P.: Pore water geochemistry of sediment core BK8, Alfred Wegener Institute - Research Unit Potsdam, doi:10.1594/PANGAEA.847262, 2015.

Overduin, P. P., Rachold, V., and Grigoriev, M. N.: The state of subsea permafrost in the western Laptev nearshore zone, in: Proceedings of the 9th International Conference on Permafrost, edited by: Kane, D. L. and Hinkel, K. M., Fairbanks, Alaska, 29 June-3 July 2008, 1345-1350, Fairbanks, Alaska, 2008.

Reimer, P. J., Bard, E., Bayliss, A., Beck, J. W., Blackwell, P. G., Bronk Ramsey, C., Buck, C. E., Cheng, H., Edwards, R. L.,
Friedrich, M., Grootes, P. M., Guilderson, T. P., Haflidason, H., Hajdas, I., Hatté, C., Heaton, T. J., Hogg, A. G., Hughen, K. A., Kaiser, K. F., Kromer, B., Manning, S. W., Niu, M., Reimer, R. W., Richards, D. A., Scott, E. M., Southon, J. R., Turney, C. S. M., and van der Plicht, J.: IntCal13 and MARINE13 radiocarbon age calibration curves 0-50000 years calBP, Radiocarbon, 55, 1869-1887, doi:10.2458/azu_js_rc.55.16947, 2013.

Reineck, H.-E. and Sing, I. B.: Depositional Sedimentary Environments, Springer, 2nd rev. and updated ed., 551 pp., 1980.

Rethemeyer, J., Dewald, A., Fülöp, R., Hajdas, I., Höfle, S., Patt, U., Stapper, B., and Wacker, L.: Status report on sample preparation facilities for $14 \mathrm{C}$ analysis at the new CologneAMS centre, Nuclear Instruments and Methods in Physics Research B, 294, 168-172, 2013.

Romanovskii, N. N., Hubberten, H.-W., Gavrilov, A. V., Tumskoy, V. E., Tipenko, G. S., Gri'oriev, M. N., and Siegert, Ch.: Thermokarst and Land-Ocean Interactions, Laptev Sea Region, Russia, Permafrost and Periglacial Processes, 11, 137-152, 2000.

Romanovskii, N. N., Hubberten, H. W., Gavrilov, A. V., Tumskoy, V. E., and Kholodov, A. L.: Permafrost of the east Siberian Arctic shelf and coastal lowlands, Quaternary Sci. Rev., 23, 1359-1369, doi:10.1016/j.quascirev.2003.12.014, 2004.

Romanovsky, V. E., Drozdov, D. S., Oberman, N. G., Malkova, G. V., Kholodov, A. L., Marchenko, S. S., Moskalenko, N. G., Sergeev, D. O., Ukraintseva, N. G., Abramov, A. A., Gilichinsky, D. A., and Vasiliev, A. A.: Thermal state of permafrost in Russia, Permafrost and Periglacial Processes, 21, 136-155, doi:10.1002/ppp.683, 2010.

Sanborn, P. T., Smith, C. A. S., Froese, D. G., Zazula, G. D., and Westgate, J. A.: Full-glacial paleosols in perennially frozen loess sequences, Klondike goldfields, Yukon Territory, Canada, Quaternary Res., 66, 147-157, doi:10.1016/j.yqres.2006.02.008, 2006.

Schirrmeister, L., Siegert, C., Kuznetsova, T., Kuzmina, S., Andreev, A. A., Kienast, F., Meyer, H., and Bobrov, A. A.: Paleoenvironmental and paleoclimatic records from permafrost deposits in the Arctic region of Northern Siberia, Quatern. Int., 89, 97-118, 2002.

Schirrmeister, L., Grosse, G., Kunitsky, V., Magens, D., Meyer, H., Dereviagin, A., Kuznetsova, T., Andreev, A., Babiy, O., Kienast, F., Grigoriev, M., Overduin, P. P., and Preusser, F.: Periglacial landscape evolution and environmental changes of Arctic lowland areas for the last 60,000 years (Western Laptev Sea coast, Cape Mamontov Klyk), Polar Research, 27, 249-272, doi:10.1111/j.1751-8369.2008.00067.x, 2008.

Schirrmeister, L., Grosse, G., Wetterich, S., Overduin, P., Strauss, J., Schuur, E. A. G., and Hubberten, H.-W.: Fossil organic matter characteristics in permafrost deposits of the Northeast Siberian Arctic, J. Geophys. Res.-Biogeosci., 116, G00M02, doi:10.1029/2011JG001647, 2011a.

Schirrmeister, L., Kunitsky, V., Grosse, G., Wetterich, S., Meyer, H., Schwamborn, G., Babiy, O., Derevyagin, A., and Siegert, C.: Sedimentary characteristics and origin of the Late Pleistocene Ice Complex on north-east Siberian Arctic coastal lowlands and islands - a review, Quatern. Int., 241, 3-25, doi:10.1016/j.quaint.2010.04.004, 2011 b.

Schirrmeister, L., Froese, D., Tumskoy, V., Grosse, G., and Wetterich, S.: Yedoma: Late Pleistocene ice-rich syngenetic permafrost of Beringia, in: The Encyclopedia of Quarternary Sci- 
ence, second edition, vol. 3, edited by: Elias, S. A., Elsevier, Amsterdam, 542-552, doi:10.1016/B978-0-444-53643-3.001060, 2013.

Schirrmeister, L., Meyer, H., Andreev, A. A., Wetterich, S., Kienast, F., Bobrov, A., Fuchs, M., Sierralta, M., and Herzschuh, U.: Late Quaternary records from the Chatanika River valley near Fairbanks (Alaska), Quaternary Sci. Rev., 14, 259-278, doi:10.1016/j.quascirev.2016.02.009, 2016.

Schneider von Deimling, T., Grosse, G., Strauss, J., Schirrmeister, L., Morgenstern, A., Schaphoff, S., Meinshausen, M., and Boike, J.: Observation-based modelling of permafrost carbon fluxes with accounting for deep carbon deposits and thermokarst activity, Biogeosciences, 12, 3469-3488, doi:10.5194/bg-12-34692015, 2015.

Sher, A. V.: Yedoma as a store of paleoenvironmental records in Beringia, in: Abstracts and Program of the Beringia Paleoenvironmental Workshop, edited by: Elias, S. and Brigham-Grette, J., Florissant, Colorado, 20-23 September 1997, 92-94, 1997.

Sher, A. V., Kuzmina, S. A., Kuznetsova, T. V., and Sulerzhitsky, L. D.: New insights into the Weichselian environment and climate of the East Siberian Arctic, derived from fossil insects, plants, and mammals, Quaternary Sci. Rev., 24, 533-569, doi:10.1016/j.quascirev.2004.09.007, 2005.

Shmelev, D., Veremeeva, A., Kraev, G., Kholodov, A., Spencer, R. G. M., Walker, W. S., and Rivkina, E.: Estimation and sensitivity of carbon storage in permafrost of North-Eastern Yakutia, Permafrost and Periglacial Processes, doi:10.1002/ppp.1933, 2017.

Shur, Y., French, H. M., Bray, M. T., and Anderson, D. A.: Syngenetic permafrost growth: Cryostratigraphic observations from the CRREL tunnel near Fairbanks, Alaska, Permafrost Periglac., 15, 339-347, doi:10.1002/ppp.486, 2004.

Souchez, R., Jouzel, J., Lorrain, R., Sleewagen, S., Stievenard, M., and Verbeke, V.: A kinetic isotope effect during ice formation by water freezing, Geophys. Res. Lett., 27, 1923-1926, doi:10.1029/2000GL006103, 2000.

Stapel, J., Schirrmeister, L., Overdiun, P., Wetterich, S., Strauss, S., Horsfield, B., and Mangelsdorf, K.: Microbial lipid signatures and substrate potential of the organic matter in permafrost deposits from Buor Khaya: implications for future greenhouse gas production, J. Geophys. Res.-Biogeosci., 121, 2652-2666, doi:10.1002/2016JG003483, 2016.

Strauss, J. and Schirrmeister, L.: Permafrost sequences of Buor Khaya Peninsula, in: Russian-German Cooperation SYSTEM LAPTEV SEA: The expedition Eastern Laptev Sea - Buor Khaya Peninsula, edited by: Wetterich, S., Overduin, P. P., and Grigoriev, M., Berichte zur Polar- und Meeresforschung (Reports on Polar and Marine Research), 629, 35-50, 2011.

Strauss, J., Schirrmeister, L., Wetterich, S., Borchers, A., and Davydov, S. P.: Grainsize properties and organic-carbon stock of Yedoma Ice Complex permafrost from the Kolyma lowland, Northeastern Siberia, Global Biochem. Cy., 26, GB3003, doi:10.1029/2011GB004104, 2012.

Strauss, J., Schirrmeister, L., Grosse, G., Wetterich, S., Ulrich, M., Herzschuh, U., and Hubberten, H.-W.: The deep permafrost carbon pool of the Yedoma region in Siberia and Alask, Geophys. Res. Lett., 40, 6165-6170, doi:10.1002/2013GL058088, 2013.

Strauss, J., Schirrmeister, L., Mangelsdorf, K., Eichhorn, L., Wetterich, S., and Herzschuh, U.: Organic-matter quality of deep permafrost carbon - a study from Arctic Siberia, Biogeosciences, 12, 2227-2245, doi:10.5194/bg-12-2227-2015, 2015.

Stuiver, M. and Polach, H. A.: Discussion: Reporting of 14C Data, Radiocarbon, 19, 355-363, 1977.

Stuiver, M. and Reimer, P. J.: Extended 14Cdata base and revised calib 3.014c age calibration program, Radiocarbon, 35, 215-230, 1993.

Suzuoki, T. and Kimura, T.: D/H and 18O/16O fractionation in ice-water system, Journal of the Mass Spectrometry Society of Japan, 21, 229-233, 1973.

Tomirdiaro, S. V.: Loess-Ice Formations in East Siberia during the Late Pleistocene and Holocene, Nauka Press, Moscow, 184 pp., 1980 (in Russian).

Tsoar, H. and Pye, K.: Dust transport and the question of desert loess formation, Sedimentology, 34, 139-153, 1987.

Tumskoy, V. E.: Osobennosti kriolitogeneza otlozhenii severnoi Yakutii v srednem Neopleistotsene e Golotsene (Peculiarities of cryolithogenesis in northern Yakutia from the Middle Neopleistocene to the Holocene), Kriosfera Zemli (Earth Cryosphere), 16, 12-21, 2012 (in Russian).

Ulrich, M., Grosse, G., Strauss, J., and Schirrmeister, L.: Quantifying wedge-ice volumes in Yedoma and thermokarst basin deposits, Permafrost Periglac., 25, 151-161, doi:10.1002/ppp.1810, 2014.

Vasil'chuk, Y. K.: Syngenetic ice wedges: cyclical formation, radiocarbon age and stable-isotope records, Permafrost Periglac., 24, 82-93, doi:10.1002/ppp.1764, 2013.

Vasil'chuk, Y. K., Vasil'chuk, A. C., Rank, D., Kutschera, W., and Kim, J. C.: Radiocarbon dating of delta O-18-delta D plots in Late Pleistocene ice-wedges of the Duvanny Yar (Lower Kolyma River, northern Yakutia), Radiocarbon, 43, 541-553, 2001.

Vonk, J. E., Sánchez-Garcia, L., van Dongen, B. E., Alling, V., Kosmach, D., Charkin, A., Semiletov, I. P., Dudarev, O. V., Shakhova, N., Roos, P., Eglinton, T. I., Andersson, A., and Gustafsson, Ö.: Activation of old carbon by erosion of coastal and subsea permafrost in Arctic Siberia, Nature, 489, 137-140, doi:10.1038/nature11392, 2012.

Walter Anthony, K. M., Zimov, S. A., Grosse, G., Jones, M. C., Anthony, P. M., Chapin II, I. F. S., Finlay, J. C., Mack, M. C., Davydov, S., Frenzel, P., and Frolking, S.: A shift of thermokarst lakes from carbon sources to sinks during the Holocene epoch, Nature, 511, 452-456, doi:10.1038/nature13560, 2014.

Wenthworth, C. K.: A Scale of Grade and Class Terms for Clastic Sediments, J. Geol., 30, 377-392, doi:10.1086/622910, 1922.

Wetterich, S., Schirrmeister, L., and Pietrzeniuk, E.: Freshwater ostracodes in Quaternary permafrost deposits from the Siberian Arctic, J. Paleolimnol., 34, 363-376, doi:10.1007/s10933-0055801-y, 2005.

Wetterich, S., Kuzmina, S., Andreev, A. A., Kienast, F., Meyer, H., Schirrmeister, L., Kuznetsova, T., and Sierralta, M.: Palaeoenvironmental dynamics inferred from Late Quaternary permafrost deposits on Kurungnakh Island, Lena Delta, Northeast Siberia, Russia, Quaternary Sci. Rev., 27, 1523-1540, doi:10.1016/j.quascirev.2008.04.007, 2008.

Wetterich, S., Schirrmeister, L., Andreev, A. A., Pudenz, M., Plessen, B., Meyer, H., and Kunitsky, V. V.: Eemian and Late Glacial/Holocene palaeoenvironmental records from permafrost sequences at the Dmitry Laptev Strait 
(NE Siberia, Russia), Paleogeogr. Paleoclim., 279, 73-95, doi:10.1016/j.palaeo.2009.05.002, 2009.

Wetterich, S., Overduin, P. P., and Grigoriev, M. (Eds.): RussianGerman Cooperation SYSTEM LAPTEV SEA: The expedition Eastern Laptev Sea - Buor Khaya Peninsula, Berichte zur Polarund Meeresforschung (Reports on Polar and Marine Research), 629, 94 pp., 2011a.

Wetterich, S., Rudaya, N., Tumskoy, V., Andreev, A. A., Opel, T., Schirrmeister, L., and Meyer, H.: Last Glacial Maximum records in permafrost of the East Siberian Arctic, Quaternary Sci. Rev., 30, 3139-3151, doi:10.1016/j.quascirev.2011.07.020, 2011 b.

Wetterich, S., Tumskoy, V., Rudaya, N., Andreev, A. A., Opel, T., Meyer, H., Schirrmeister, L., and Hüls, M.: Ice Complex formation in arctic East Siberia during the MIS3 Interstadial, Quaternary Sci. Rev., 84, 39-55, doi:10.1016/j.quascirev.2013.11.009, 2014.

Winterfeld, M., Goñi, M. A., Just, J., Hefter, J., and Mollenhauer, G.: Characterization of particulate organic matter in the Lena River delta and adjacent nearshore zone, NE Siberia - Part 2: Lignin-derived phenol compositions, Biogeosciences, 12, 22612283, doi:10.5194/bg-12-2261-2015, 2015.
Yakshina, I.: Study of soils and flora of the western coast of the Buor Khaya Peninsula, Berichte zur Polar- und Meeresforschung (Reports of Polar and Marine Research), 629, 5-10, 2011.

Zimmermann, H. H., Raschke, E., Epp, L. S., Stoof-Leichsenring, K. R., Schwamborn, G., Schirrmeister, L., Overduin, P. P., and Herzschuh, U.: Sedimentary ancient DNA and pollen reveal the composition of plant organic matter in Late Quaternary permafrost sediments of the Buor Khaya Peninsula (north-eastern Siberia), Biogeosciences, 14, 575-596, doi:10.5194/bg-14-5752017, 2017.

Zimov, S. A., Davydov, S. P., Zimova, G. M., Davydova, A. I., Schuur, E. A. G., Dutta, K., and Chapin, F. S.: Permafrost carbon: Stock and decomposability of a globally significant carbon pool, Geophys. Res. Lett., 33, L20502, doi:10.1029/2006g1027484, 2006. 